ISSN 1696-0300

\title{
UN SOL ESPLENDOROSO EN LEÓN: EL JUDÍO HASDAY DE CÓRDOBA (941-956)
}

\author{
Manuel CARRIEDO TEJEDO \\ Director del Archivo Histórico de Caja España
}

\begin{abstract}
RESUMEN: Hasday b. Saprut, el judío europeo más importante de la décima centuria, un hombre sinceramente preocupado por todos sus correligionarios de los cuatro puntos cardinales entonces conocidos, también residió en León (como embajador califal) durante 941 por espacio siete meses (en los días del gran Ramiro II, con quien llegó a mantener sincera amistad) y durante 956 por otro período indeterminado (reinando Ordoño III, hijo del anterior); sin olvidar que luego siguió teniendo contacto, ahora ya en calidad de médico y diplomático, con el rey Sancho I (956-966). Y, por otro lado, la ausencia absoluta de noticias sobre los judíos en todo el ámbito de la vieja provincia "Gallaeciae" suevo-visigoda (ss. VI-VII) y altomedieval (ss. VIII y IX), se ve interrumpida precisamente en León (y sólo en la "urbe regia" legionense, de forma excepcional) con la aparición estable de hebreos muy poco tiempo después de morir Hasday (hacia 975). Una asociación de datos que conviene tener muy en cuenta a la hora de explicar los orígenes mismos de la comunidad judía leonesa, fraguada con muchas probabilidades a mediados del siglo X, e initerrumpidamente visible en la documentación desde 977 (y hasta 1492).
\end{abstract}

PALABRAS CLAVE: Judíos en León (siglo X) - Hasday b. Saprut - Reino de León - Califato de Córdoba - Tratados de paz - Embajadas.

ABSTRACT: Hasday ben Saprut was the most important European Jew of the tenth century. He lived in León, Spain, in 941 and in 956, and after that maintained his ties with King Sancho I as doctor and diplomat. The stable presence of Jews in León would develop only after Hasday's death, sometime around 975. Thus, we find that Leon's Jewish community was becoming established in the mid-tenth century, and it is documented continuously from 977 until 1492.

KEYWORDS: Jews in León-Hasday ben Saprut-León Kingdom- caliphate’s Córdoba- Peace TreatyEmbassy.

Abu Yusuf Hasday ben Ishaq ben 'Ezra' ibn Saprut al-Isra'ili (910-975) era persona sin par en su tiempo entre los servidores de los reyes por su cultura, habilidad y sutileza, dice en el tomo $\mathrm{V}$ de su "Muqtabis" el gran historiador cordobés Ibn Hayyan (s. XI), al referirse al que sin duda fue el judío más 
importante de todo el occidente a la largo de la décima centuria ${ }^{1}$, de quien sabemos además, gracias al "Libro de Poética" de Moseh ibn 'Ezra' (ss. XI-XII), que el lugar de su origen fue Jaén, y el de su grandeza Córdoba². Una excelencia que todavía era recordada muchas décadas después, a través de la pluma de Yehudah al-Harizi (ss. XII-XIII), en su libro "Sefer Tahkemoni": En aquellos días lució en Sefarad un esplendoroso sol en el gran firmamento: el gran príncipe... Hasday ${ }^{3}$.

Médico, alto funcionario califal, polígloto y mecenas de la cultura, nuestro singular personaje visitó el reino legionense en calidad de embajador de 'Abdarrahmán III en dos ocasiones, ante el gran Ramiro II de León (en 941) y ante su hijo Ordoño III (en 956), y sabemos que luego tuvo un protagonismo insustituible al lado de Sancho I el "Gordo" en 958. Todo lo cual vino a significar con muchas probabilidades un punto y aparte en el afianzamiento (y tal vez en el establecimiento mismo) de la que después se convirtió en importantísima comunidad judía de León, la tercera y última "urbe regia" de los godos, que curiosamente es también la única ciudad del noroeste hispano (esto es, de la vieja provincia "Gallaeciae") donde es posible documentar la existencia de hebreos durante toda la décima centuria ${ }^{4}$.

Y si hay un personaje, probablemente el único en toda la península, de quien podemos asegurar que compartía la más alta consideración y la sincera estima por parte de los dos grandes monarcas hispanos del siglo X, 'Abdarrahmán III (912961) y Ramiro II (931-951), ese fue, sin duda, el judío Hasday ${ }^{5}$.

${ }^{1}$ IBn HAYYan; trad. Viguera, M.J. y F. CORRIENTE, F. (1981). Crónica del califa 'Abdarrahmán III an-Nasir entre los años 912 y 942 (al-Muqtabis V). Zaragoza: Anubar; Instituto Hispano-Árabe de Cultura, p. 350.

2 Moseh Ibn 'EzRA'; vid. G. MaEso (1956). "Un jaenés ilustre, ministro de dos califas (Hasday ibn Saprut)". Boletín del Instituto de Estudios Gienenses, 8, p. 71.

3 Al-Harizi; vid. Del Valle RodríGuez, C. (1981). La Escuela Hebrea de Córdoba. Los orígenes de la Escuela filológica hebrea de Córdoba. Madrid: Editora Nacional, p. 83.

4 Vid. Carriedo Tejedo, M. (2008). "Judíos en la provincia de «Gallaecia»". Estudios Mindonienses (= EM), 24., pp. 305-382.

${ }^{5}$ Vid. etiam lo dicho al respecto de Hasday por: SuÁrez, L. (1980). Los judíos. Madrid: Ariel, p. 273; Beinart, H. (1993). Los judíos en España. Madrid: Mapfre, p. 51; Carrete Parrondo, C. (1992). "El legado renovador de los judíos españoles". En Peláez del Rosal, J. (ed.). De Abrahán a Maimónides. III. Los judíos en Córdoba (ss. X-XII) (= De Abrahán a Maimónides). Córdoba: El Almendro, pp. 32-33; NAVARRo PeIRÓ, M.A. (1992). "Panorámica de la literatura hispanohebrea". De Abrahán a Maimónides, pp. 47-48; PÉLÁEz Del RosAl, J. (1992). "Hasday ibn Saprut en la corte de Abderramán". De Abrahán a Maimónides, pp. 63-77; SÁENZ-BADIllos, A. (1992). "Poetas judíos en Córdoba". De Abrahán a Maimónides, pp. 80-81; VArela Moreno, E. (1992). "La escuela de gramáticos hebreos de Córdoba". De Abrahán a Maimónides, p. 108; RomANo, D. (1992). La ciencia 


\section{LOS JUDÍOS EN LEÓN ANTES DE HASDAY [897-940]}

Anexionado el viejo campamento militar legionense por Ordoño I (850-866), concretamente durante el trienio 854-856 (in era DCCCLXLIIII populabit domnus Ordonius Legione et in tertio anno sic fregit ${ }^{6}$ ), y convertido casi de inmediato en sede de un nuevo obispado (Ordoño... fue el primero... en elevar en esta ciudad un obispo $)^{7}$, sabemos que durante su repoblación fue ocupado con cristianos procedentes tanto del norte cristiano (gallegos, bercianos, asturianos, gordoneses, lebaniegos, vascones y castellanos) como del propio emirato (toledanos, cordobeses y caurienses, entre otros $\left.^{8}\right)$ : Ordoño... las ciudades de antiguo abandonadas, es decir, León, Astorga, Tuy... las rodeó de muros, las puso altas puertas, y las llenó de gentes, en parte de las suyas, en parte de las llegadas de España ${ }^{9}$. Una labor colonizadora que fue continuada por su hijo y sucesor Alfonso III (866-910) de forma sistemática en todo el reino (el serenísimo príncipe don Alfonso... erigió aldeas y castillos, fortificó ciudades y pobló villas, colocó mojones ciertos dividiendo unos y otros habitantes, y todo lo ordenó y dispuso $)^{10}$ y naturalmente en la propia ciudad de León, previo el correspondiente edicto (ad populacionem de Legione, ad editum regis... domni Adefonsi principi $)^{11}$. De modo que Sánchez-Albornoz se pregunta con razón: "¿No se unirían a veces a tales

hispanojudía. Madrid: Mapfre, pp. 40-41; Montes Romero-CAMACHO, I. (2001). Los judíos en la Edad Media española. Madrid: Arcos Libros, p. 17; y VALLVÉ, J. (1986). La división territorial de la España musulmana. Madrid: Consejo Superior de Investigaciones Científicas, Instituto de Filología, p. 451.

${ }^{6}$ Anales Castellanos Primeros; vid. ed. Gil Fernández, J., Moralejo, J.L. y Ruiz De La PeÑa, J.I. (1985). Crónicas asturianas. Crónica de Alfonso III -Rotense y "A Sebastian"-, Crónica Albeldense -y "Profética"-. Introducción y edición crítica. Traducción y notas. Estudio preliminar. Oviedo : Universidad, pp. 76-77.

${ }^{7}$ Carta de 1073; ed. Ruiz AsEncio, J.M. (1990). Colección documental del Archivo de la catedral de León (775-1230), IV (1032-1109). León: Centro de Estudios e Investigación "San Isidoro"; Caja España; Archivo Histórico Dicoesano, doc. 1190.

${ }^{8}$ Sin salir del entorno de la meseta leonesa, todavía es posible visitar hoy, por poner algunos ejemplos, localidades llamadas Toldanos, diversos Bercianos, Galleguillos, Castellanos y Gordoncillo.

${ }^{9}$ Crónica de Alfonso III; trad. MoRALEJo, Crónicas asturianas, p. 220.

10 Documento de Odoyno: Archivo Histórico Nacional (= AHN), Tumbo de Celanova, ff. 97v100v; trad. Prieto Prieto. A. (1993). El reino de León hace mil años más o menos. León: Universidad, pp. 70-71.

${ }^{11}$ Carta de 915; ed. SÁEz, E. (1987). Colección documental del Archivo de la catedral de León (775-1230), I. (785-952). León: Centro de Estudios e Investigación "San Isidoro"; Caja España; Archivo Histórico Dicoesano, doc. 34. 
emigrantes de las ciudades islamitas del centro de España algunos conciudadanos hebreos acostumbrados a vivir entre ellos y quizá a vivir de ellos?"12.

El primer testimonio conocido sobre la segura existencia de un hebreo en la ciudad de León corresponde a la carta original fechada el 21 de mayo de 897, en cuya virtud una mujer llamada Nunilo (hija de Julián) y su hijo Bonello, venden a un tal Apaz una tierra en el territorio de León, al "Castro del Rey", en la ribera del río Torío (terra in territorio Legionense, ad Castrum de Rege, super ripam fluminis Turio), esto es, en el actual barrio leonés de Puente Castro ${ }^{13}$. En ningún momento se dice en la carta, es verdad, que Apaz fuese judío, pero lo sabemos gracias a otra escritura poco posterior, fechada el 22 de abril de 905, por la que el presbítero Lázaro (que también confirma el diploma de 897) dona a Cixila y a los monjes del monasterio de San Cosme y San Damián de Abellar (muy próximo a León, en la ribera del río Torío) lo que en su día le había entregado a él dicho Apaz (o Habaz), del que se añade haber sido "judío en otro tiempo, y luego cristiano y monje" (quondam iudeus, postea uero christianus et monacus) ${ }^{14}$. Una apostasía, el único caso conocido entre judíos del norte cristiano durante los primeros siglos de la Edad Media, que en sí misma constituye un significativo indicio sobre la ausencia de una comunidad estable de hebreos en León, sobre los que nada más volvemos a saber, a pesar de las apariencias: ¿Era judío el Abaom Mari que aparece radicado en la ribera del Bernesga en $921 ?^{15}$, ¿̇lo eran el Zayhet y la Xaba que en 926 son mencionados como propietarios en Marialba de la Ribera? ${ }^{16}$, ¿eran hebreos leoneses los dos confirmantes, Susanna et Ebraheme, de una escritura de 930 relacionada con la venta de una viña en el río Torío ${ }^{17}$ Tal vez no lo sepamos nunca ${ }^{18}$.

12 Vid. C. SÁnChez-Albornoz (1980), "Los judíos en los reinos de Asturias y León". Viejos y nuevos estudios sobre las instituciones medievales españolas, III, Madrid: Espasa Calpe, pp. 16211630.

${ }^{13}$ Archivo Catedral de León (= ACL), nº 233; ed. SÁEz, Colección catedral de León, I, doc. 12.

${ }^{14}$ ACL, Tumbo de León (= TL), ff. 392v-393r; ed. ID., ibid., doc. 19.

${ }^{15}$ ACL, $\mathrm{n}^{\circ}$ 63; ed. ID., ibid., doc. 53.

${ }^{16}$ ACL, TL, f. 434r; ed. ID., ibid., doc. 70.

${ }^{17}$ ACL, TL, f. f. 446r-v; ed. ID., ibid., doc. 85.

${ }^{18}$ En consecuencia, al evitar las especulaciones basadas en la simple coincidencia onomástica no podemos asumir las identificaciones que sin otros apoyos hace RoDRíGUEZ FERNÁNDEZ, J. (1969). La judería de la ciudad de León. León: Centro de Estudios e Investigación "San Isidoro"; Caja España; Archivo Histórico Dicoesano; y mucho menos las que trae a cuento en su recientísimo estudio FERNÁNDEZ CONDE, J. (2007). "Poblaciones foráneas; mozárabe, musulmana y judía en el Reino de León". Monarquía y sociedad en el Reino de León. De Alfonso III a Alfonso VII. León: Centro de Estudios e Investigación "San Isidoro"; Caja España; Archivo Histórico Dicoesano, p. 812. Sí 
Desde luego, creemos que hoy lo único que podemos hacer es buscar apoyo en los testimonios que constatan de forma expresa la condición de "iudeus" o de "hebreo", pues lo cierto es que el argumento puramente onomástico no sólo contribuye a diluir el conocimiento de la verdad histórica, desvirtuando fatalmente la información que las fuentes seguras nos brindan (cronología, onomástica, noticias biográficas, número de individuos, propiedades, naturaleza de los cultivos, oficios, asentamientos geográficos, relaciones de parentesco), sino que, además, resulta ser muy endeble, teniendo en cuenta que no pocos cristianos, incluso clérigos, lucieron emblemáticos nombres judíos: Elias presbiter (870), Samuel abba (906), Abdie abba (925), Daniel presbiter (935), Aaron presbiter (957), Levi confessor (959), Abraham confessor (959), Habaz filii Froilani (959), Moysen presbiter (980), Iacobus episcopus (981), Dauid frater (984) y Salomón episcopus $(985)^{19}$.

No será hasta el verano de 940 cuando se documente la existencia segura de otro judío en León, de nombre Baruj, esta vez al servicio directo del rey Ramiro, interesado por ese entonces en contactar diplomáticamente con 'Abdarrahmán III (llamado an-Nasir), lo que no pudo consumarse debido a la oposición de caíd de la frontera Ahmad b. Ilyas (colega de Hasday, y por ese entonces presidente del Colegio de Médicos de Córdoba $^{20}$ ), quien no dio las facilidades necesarias al efecto, según lo recogido por Ibn Hayyan: En este año fueron frecuentes la cartas de Ramiro hijo de Ordoño, rey de los leoneses, pidiendo paz y tregua, para lo que había enviado un mensaje al caíd Ahmad b. Muahammad b. Ilyas, acampado en su zona con el ejército de la aceifa, con su mensajero, el judío Baruj, pidiéndole que intercediera ante an-Nasir con dilatada solicitud, mas obteniendo de Ibn Ilyas una respuesta ruda y amenazadora ${ }^{21}$. Una presencia, la del judío Baruj en el palacio de

compartimos, desde luego, la opinión de EstePa DíEz, C. (1977). Estructura social de la ciudad de León (Siglos XI-XIII). León: Centro de Estudios e Investigación "San Isidoro"; Caja España; Archivo Histórico Dicoesano, p. 163: "En muchos diplomas los encontramos como ebreos, lo cual nos da a entender no sólo la necesidad de hacer constar su vinculación religiosa y social que les diferencia del resto de la población cristiana, sino también para distinguirlos de los mozárabes, debido a sus coincidencias onomásticas; así, por ejemplo, cuando aparecen judíos llamados Aziz, Iucef, Abozehar..., nombres utilizados por la población mozarabizada, era necesario hacer constar que se trataba de judíos".

${ }^{19}$ Estos y otros muchos nombres de igual factura son de fácil localización en cualquier colección documental del noroeste hispano. Sólo en casos muy concretos en los que puede sumarse el simple argumento onomástico a la coincidencia documental con otros judíos declarados, y en relación con localidades de tradición judía, podrían plantearse identificaciones aceptables.

${ }^{20}$ IBN Yulyul; trad. VeRNET, J. (1968). "Los médicos andaluces en el "Libro de las Generaciones de Médicos", de Ibn Yulyul". Anuario de Estudios Medievales. 5, p. 460.

${ }^{21}$ IBn HAYYAN; trad. Viguera y CORRIENTE, Crónica del califa, p. 344. 
León, que resulta ser significativamente sincrónica con la presencia de otros judíos al servicio de otros señores peninsulares.

En efecto, sabemos que en 940 las naves de guerra califales tomaron rumbo a Tortosa (ciudad grande, construida sólidamente... en la margen occidental del Ebro, junto a la desembocadura en el mar, donde está su Puerta Mayor ${ }^{22}$ ), a fin de atacar desde aquí la próxima Barcelona (ciudad en la orilla del mar, en cuyo puerto hay escollos que impiden entrar sin prácticos muy experimentados en aquella navegación: tiene arrabal y fuertes murallas ${ }^{23}$ ), a la que previamente había llegado por tierra un agente fiscal cordobés o amin, que ya se había dirigido al jefe de ellos (los barceloneses)... para reclamar la capitulación (impuesto), al mismo tiempo que ordenaba a las naves califales que no causasen dificultades a la ciudad ni a las gentes de su litoral, con lo que finalmente la escuadra emprendió el regreso hacia Tortosa ${ }^{24}$. Un pasaje que viene a ser ratificado por Ibn Hayyan, pues nos descubre además que el referido amin (agente fiscal del califa) no era otro que el judío Hasday, aquí mencionado por vez primera al servicio directo de 'Abdarrahmán III, en su doble vertiente de funcionario y embajador ante el conde Suñer de Barcelona (912-951): En este año [328 H. = 18 octubre 939 - 5 octubre 940] hizo el secretario judío Hasday ben Ishaq la paz con el franco Suñer hijo de Wifredo, señor de Barcelona y sus distritos, exclusivamente en los términos gratos a an-Nasir, enviando a Hasday a Barcelona para concluir dicha paz [...] Se dio la casualidad de que llegó la escudra, procedente de Almería... al mando de Ibraim b. 'Abdarrahmán... a Barcelona, el viernes, 10 de sawwal [19 julio 940], comunicándole Hasday la paz hecha con... Suñer, y deteniendo el ataque [...] Hasday propuso a los notables de Barcelona que se sometieran a an-Nasir $e$ hicieran la paz con él, a lo que accedieron algunos [...] El judío Hasday b. Ishaq volvió a an-Nasir desde Barcelona a fines de du-l-qa'da [6 septiembre 940] en compañía del mensajero de Suñer, al que siguieron otros, como el legado de Riquilda, hija de Borrell, señora de algunos francos [como viuda que era de Odón de Narbona], que en efecto imitó a Unyu [¿Hugo de Provenza?] en su paz con anNasir, enviádole a su hombre de confianza, el judío Bernat, con peregrinas

22 Dikr bilad al- Andalus; ed. y trad. Molina, L. (1983). Una descripción anónima de alAndalus, II. Traducción y estudio. Madrid : Consejo Superior de Investigaciones Científicas, Insttituto "Miguel Asín", p. 80.

23 AL-IDRISI; trad. SAAVEDRA, E. (1881). La geografía de España del Edrisí. Madrid, reed., Valencia ("Textos Medievales; 37) 1974, p. 147.

${ }^{24}$ AL-’UdRI; trad. SÁNCHEZ-MARTínEZ, M. (1972). "La cora de Ilbira (Granada y Almería) en los siglos X y XI, según al-’Udri (1003-1085)". Cuadernos de Historia del Islam, 3, pp. 30-31. 
preciosidades de su país, que an-Nasir aceptó y retribuyó con otras más preciosas, agasajando a sus mensajeros ${ }^{25}$.

Dos territorios peninsulares, los de León (sin tradición local judía) y Barcelona (centro de una significada comunidad hebrea), donde no es extraño que sus gobernantes imitaran la iniciativa cordobesa de poner a judíos (previsiblemente bilingües) al frente de misiones diplomáticas. Pero además, el servicio prestado por Baruj a Ramiro II (en 940) viene a revelarnos de igual modo la tolerancia que durante el siglo $\mathrm{X}$ mostraron hacia los judíos los neogóticos monarcas de la "Gallaecia", capitalizados en León (en contraposición a la actitud claramente enemiga de sus predecesores, los monarcas godos de Hispania, capitalizados en Toledo), en consonancia con los nuevos tiempos que corrían en la décima centuria, marcada por la presencia en la península de un próspero y poderoso califato occidental.

\section{RELACIONES ENTRE LEÓN Y CÓRDOBA [931-940].}

Durante la primera mitad del siglo $\mathrm{X}$ se nos muestran los que sin duda fueron los dos monarcas hispanos más importantes, cada uno en su ámbito: ‘Abdarrahmán III an-Nasir (conocido por los cristianos como Habdirrahmen filio Muhammed nepos Habdalla) y Ramiro II (llamado en las crónicas árabes Rudmir b. Urdun b. Adfuns). Dos referentes obligados de sus respectivas dinastías que consiguieron la mayor influencia para sus reinos y el más alto brillo en sus capitales: Ni Córdoba había conocido con los omeyas (ni conocería después) semejante esplendor, ni León había vivido (ni viviría después con esta dinastía) tamaño protagonismo y peso específico a nivel peninsular.

Pues bien. Teniendo en cuenta que la primera estancia leonesa de Hasday (en el año 941) fue producto de guerras previas y de muy intensas relaciones diplomáticas entre Córdoba y León, parece conveniente traer aquí a colación el relato muy resumido de los sucesos relativos a la década inmediatamente anterior (931-940), muy condicionados a su vez por las frecuentes rebeliones que tuvo que aplastar el joven 'Abdarrahmán III al comienzo de su reinado (heredadas del reinado de su abuelo), que se habían extendido incluso a los distritos fronterizos: Évora (915), Badajoz (929), Toledo (930), Zorita (926), Calatayud (924), Maluenda (934), Daroca (935), Zaragoza (935), Rueda de Jalón (934), Tudela (923), y Barbastro (935); pues lo cierto es que en tales circunstancias la política de exterior de los reyes leoneses resultó ser muy oportunista, como era obligado, especialmente por parte del rey Ramiro:

${ }^{25}$ IBn HAYYAN; trad. Viguera y CoRRIENTE, Crónica del califa, pp. 341-342. 
- Año 931 (fallido intento leonés de ayuda a Toledo): Supo entonces an-Nasir que el enemigo planeaba una salida contra la Marca Superior... al concocer que estaba ocupado con los toledanos... por lo que ordenó que machara... el visir y el caíd Ahmad b. Muhammad b. Hudayr... contra el enemigo, el cual... desistió de la incursión... sin salir de su tierra ${ }^{26}$.

- Año 932 (ataque leonés a Madrid): Los pertinaces toledanos, acosados por el duro asedio... habían pedido ayuda a sus vecinos, los enemigos infieles... les enviaron un gran refuerzo de sus mejores guerreros ${ }^{27}$, que atacaron la plaza de Madrid: Ramiro... reunido ejército, avanzando a la ciudad que se llama Madrid, destrozó sus muros e hizo grandísimos estragos ${ }^{28}$.

- Año 933 (ataque cordobés a Osma): Mas residiendo [Ramiro] en León vino emisario de Fernán González sobre grande expedición que adelantaba hacia Castilla. Lo que oído, movilizó el ejército el rey, y salió al encuentro de ellos en el lugar que se dice Osma... dióle el Señor gran victoria ${ }^{29}$.

- Año 934 (ataque cordobés a Coruña del Conde): Se detuvo [an-Nasir en Clunia]... encontrando congregados a los infieles en ella, pues habían entrado con caballeros e infantes... con ellos estaba su rey, el tirano Ramiro hijo de Ordoño, y todos los condes, preparados para un encuentro con los musulmanes, con sus escuadrones formados, aunque el califa, enterándose... de la escasez que había este año en la región de la fortalezas del Duero... temiendo estrecheces para lo suyos, desistió de su proyectada penetración de castigo, pareciéndole más oportuno y seguro regresar ${ }^{30}$.

- Año 935 (relaciones diplomáticas): Ramiro II intenta por vez primera un contacto amistoso con la corte cordobesa, que envió a León como embajador a Yahyà b. Ishaq: En este año an-Nasir hizo la paz con Ramiro hijo de Ordoño... tras pedírsela aquél con repetidos mensajeros... para ratificar sus cláusulas, envió al visir Yahyà b. Ishaq a la capital de Ramiro, hasta concluirla ${ }^{31}$. Una paz que en efecto aceptó el califa, preocupado como estaba

${ }^{26}$ IBN HAYYAN; trad. ID., ibid., p. 216.

${ }^{27}$ IBN HAYYAN; trad. ID., ibid., p. 238.

${ }^{28}$ SAMPIRO, Crónica; trad. GómEZ-Moreno, M. (1921). Introducción a la Historia Silense, con versión castellana de la misma y de la crónica de Sampiro. Madrid : Junta para la ampliación de estudios e investi igaciones científicas, Centro de Estudios Históricos, p. CIII.

${ }^{29}$ SAMPIRO, Crónica; trad. ID., ibid., p. CIII.

${ }^{30}$ IBn HAYyan; trad. Viguera y CORRIENTE, Crónica del califa, p. 255 y p. 256.

${ }^{31}$ IBN HAYYAN; trad. ID., ibid., pp. 273-274. 
por la disidencia de Zaragoza (la ciudad de Zaragoza y la de Astorga son semejantes en cuanto al trazado, la construcción, la fábrica y la solidez, no hay ninguna otra ciudad que se les parezca, si bien Zaragoza tiene mayor extensión ${ }^{32}$ ), gobernada entonces por Muhammad b. Hasim at-Tuyibi: Se había decidido [el califa] a esta paz con el tirano para cortar la ayuda que daba al rebelde señor de Zaragoza, Muhammad b. Hasim, tema sobre el que habían mantenido correspondencia ${ }^{33}$.

- Año 936 (intervención leonesa en el Ebro): En Córdoba se albergaban serias sospechas sobre el entendimiento entre el monarca leonés y el disidente zaragozano (ante el rumor de la violación de lo pactado por el tirano Ramiro... an-Nasir mandó... un numeroso ejército a la marca zaragozana), lo que no tardó en ser constatado (violó el tirano Ramiro... la paz, al pedirle socorro el rebelde Muhammad b. Hasim, señor de Zaragoza, contra los musulmanes), con lo que 'Abdarrahmán se vio obligado a enviar a Zaragoza otro ejército... al ser pública la noticia de la violación de lo pactado por el tirano Ramiro ${ }^{34}$, quien, en efecto, reunido un ejército avanzó a Zaragoza... subyugó todos los castillos que Abohahia [Muhammad b. Hasim] tenía hostiles y se los entregó y volvió a León con gran victoria ${ }^{35}$.

- Año 937 (rebeliones y diplomacia): ‘Abdarrahmán III hubo de hacer frente ahora a otra inquietante rebelión en el occidente, encabezada por su propio pariente Umayya b. Ishaq b. Muhammad al-Qurasi (residía en Santarem, ciudad que formaba parte de las fronteras de Al-Andalus. $)^{36}$, el cual fue combatido con rapidez con parte del ejército para cerrar la brecha rápidamente, con órdenes de marchar aceleradamente y quemando etapas, mientras él mismo [el califa] mantenía su rumbo sin desviarse... en dirección a Zaragoza $^{37}$. De modo que al mismo tiempo que an-Nasir enviaba una embajada ante Ramiro II, encabezada por el metropolitano Julián de Sevilla (Julianus hispalensis episcopus), el alfaquí Yahyà b. Zakariyya (Iahia iben Cechri) y 'Abdallah b. 'Umar (Habdela iben Aumar), señor de Alcácer do

32 Al-'Udri; trad. De La Granja, F. (1966). La Marca Superior en la obra de al-'Udri. Zaragoza: Escuela de Estudios Medievales, Consejo Superior de Investigaciones Científicas, p. 12.

33 IBN HAYYAn; trad. Viguera y CORRIEnTe, Crónica del califa, p. 274.

${ }^{34}$ IBN HAYYAN; trad. ID., ibid., pp. 283-284.

35 SAMPIRO, Crónica; trad. GÓMEZ-Moreno, Introducción a la Historia Silense, p. CIII.

36 Al-HimYari; trad. E. Lévi-Provençal, vid. SÁNChEz-Albornoz, C. (1973). La España musulmana. Madrid: Espasa Calpe, p. 339.

${ }^{37}$ IBN HAYYAN; trad. VigueRA y CORRIENTE, Crónica del califa, p. 294. 
Sal, a fin de asegurarse la neutralidad de Ramiro II en el conflicto del Tajo ${ }^{38}$, lo cierto es que en el Ebro era sometido finalmente Mahammad b. Hasim de Zaragoza, y perdonado por el califa, a condición de cortar toda relación, oculta y manifiesta, con los infieles desde los confines de Barcelona, a Boltaña, a Pamplona, a Álava, a al-Qila' [Castilla] y hasta Yilliqiyya ["Gallaecia"], no escribiéndoles ni tratándolos, sino repudiándolos como el califa, mandando incursiones a su país y no reconciliándose con ellos en ningún punto de la frontera, salvo con permiso y reiterada consulta al califa ${ }^{39}$.

- Año 938 (intervención leonesa en el río Tajo): Ramiro se volcó entonces con el rebelde de Santarén (ciudad grande y antigua, posee un gran mezquita aljama... baños espléndidos y zocos amplios y ordenados... cuenta con una importante muralla y torres tan fortificadas que no puede ser tomada por la fuerza $^{40}$ ), con lo que an-Nasir no tardó en enviar al caíd Ahmad $b$. Muhammad b. Ilyas de campaña contra los leoneses de occidente, a quien Dios destruya, cuando residía en Badajoz para combatir al perverso Umayya b. Ishaq al-Qurasi, sublevado entonces en Santarén, extremo occidental de al-Andalus. Recibida la orden, partió contra los infieles... encontrándole la mesnada enemiga dentro de Yilliqiyya [...] los derrotó e hizo una carnicería en ellos... enviando 200 cabezas cortadas, de zamoranos especialmente ${ }^{41}$.

- Año 939 (guerra abierta): Al fin fue conquistada la ciudad de Santarén en el extremo occidental de Al-Andalus, desleal bajo el traidor Umayya... que fue al tirano Ramiro hijo de Ordoño a pedirle ayuda contra el islam... Ahmad b. Yahyà b. Ilyas y el eunuco mayor Ibrahim... entraron en ella el domingo, quedando 6 noches de rabi' I [20 enero 939] ${ }^{42}$. Y lo cierto es que la estancia en León de Umayya resultó ser muy ventajosa para el rey cristiano: Se puso al servicio de Ramiro, rey de los gallegos ["galaicos"]; le ayudó contra los musulmanes y le suministró informes sobre los puntos débiles de su línea de defensa... marchó entonces junto a Ramiro, quien le acogió bien, le nombró

38 Vid. CARRIEdo Tejedo, M. (2005). "¿Tres embajadores califales recibidos en Astorga por Ramiro II en el año 937?". Astorica, 24, pp. 67-98.

39 IBN HAyyAn; trad. Viguera y CORRIENTE, Crónica del califa, p. 304.

${ }^{40}$ Dikr bilad al- Andalus; trad. Molina, Una descripción anónima de al-Andalus, p. 58.

${ }^{41}$ IBN HAYYAN; trad. VigUera y CORRIENTE, Crónica del califa, p. 318.

${ }^{42}$ IBN HAYYAN; trad. ID., ibid., pp. 321-322. 
su ministro y le admitió en el número de sus cortesanos ${ }^{43}$, y especialmente útil, cabe pensar, en el transcurso del choque a campo abierto que no tardó en producirse (durante el pleno estío) entre cristianos y musulmanes: El rey Abderrahman se apresuró hasta Simancas con gran ejército. Nuestro católico rey... dispuso ir hasta Allá con gran ejército ${ }^{44}$. Según el mismo historiador cordobés, allí fue hecho prisionero, el mismo día 6 de agosto de 939 en que se inició el combate, el antiguo aliado del rey Ramiro, Muhammad b. Hasim de Zaragoza, quien tras haberse adelantado con un destacamento de caballería y cruzado el río de Simancas, llamado Pisuerga, que está cerca de la ciudad, encontró al enemigo al otro lado del río, congregado en el llano que hay entre la ciudad y el Pisuerga, trabando duro combate... hasta que Muhammad fue desmontado y, al apearse, abandonado por los suyos y no pudiendo recuperar el caballo, se le echaron encima a montón los enemigos de Dios: al no socorrerle la caballería, fue cogido prisionero, de modo que las líneas cristianas se rehicieron y los derrotaron en vergonzosa desbandada, con enormes pérdidas... muchos murieron o fueron llevados cautivos y se perdió el real del ejército, con el pabellón y los enseres del sultán, incluido su propio corán y su cota preferida ${ }^{45}$, con lo que la victoria de los cristianos fue completa, pues los nuestros llevaron muchos despojos, a saber oro, plata y vestidos preciosos. El rey [Ramiro], ciertamente ya seguro, avanzó hacia su casa con gran victoria ${ }^{46}$, hasta el punto de que, desde entonces, el califa no volvió a salir en campaña, quedándose siempre en su capital ${ }^{47}$. Y si el desastre no fue mayor para los musulmanes se debió sin duda a la intervención del tránsfuga de Santarén: Se dice que fue Umaiya ben Ishaq quien impidió a Ramiro que persiguiera a los sobrevivientes del ejército musulmán; le puso en guardia contra una emboscada posible y le aconsejó que era mejor apoderarse de las riquezas, de las armas y de las tiendas... sin su intervención el ejército musulmán entero hubiera sido aniquilado ${ }^{48}$.

43 AL-HimYARI; trad. Lévi-Provençal, vid. SÁnchEZ-AlboRnoz, La España musulmana, pp. 339340. También AL-BAKRI; trad. VidAl BeltRÁN, E. (1982). Geografía de España. Zaragoza (Textos Medievales, 53), p. 21.

\footnotetext{
${ }^{44}$ SAMPIRO, Crónica; trad. GómEZ-MOREno, Introducción a la Historia Silense, p. CIV.

${ }^{45}$ IBn HAYyan; trad. Viguera y CoRriente, Crónica del califa, p. 325 y p. 326.

${ }^{46}$ SAMPIRO, Crónica; trad. GÓMEZ-MORENO, Introducción a la Historia Silense, p. CIV.

${ }^{47}$ IBN HAYYAN; trad. VigUERA y CORRIENTE, Crónica del califa, p. 336.

${ }^{48}$ AL-HimYARI; trad. Lévi-Provençal, vid. SÁNCHEZ-AlbORNOZ, La España musulmana, p. 40.
} 
- Año 940 (intensa actividad diplomática): Profundamente dolido por la derrota, el califa proyectó en el mes de marzo una nueva campaña contra el reino leonés, mas entonces llegó un mensajero del tirano Ramiro... pidiendo tregua, a lo que an-Nasir se inclinó... desistiendo de la expedición... fue, pues, a palacio y respondió a la carta de Ramiro, enviándole a su hombre de confianza para entrevistarse con él y concluir la paz, mientras él esperaba el resultado ${ }^{49}$. En efecto, durante la primavera y el verano de dicho año fueron frecuentes la cartas de Ramiro hijo de Ordoño, rey de los leoneses, pidiendo paz [según dijimos arriba al hablar del judío Baruj, mensajero de Ramiro II], de modo que el califa transigió y le mandó a Ahmad b. Ya'la b. Wahb... para concluir las cláusulas de la paz, teniendo lugar su salida de Córdoba a principios de ramadán [10 junio 940], de donde regresó el embajador califal a fines de sawwal [7 agosto]... procedente de Yilliqiyya, de parte de su tirano Ramiro hijo de Ordoño, con... embajadores para concluir la paz, habiendo durando la estancia en misión... 47 días desde su salida de Córdoba a su regreso. An-Nasir se informó de los deseos de los mensajeros de Ramiro acerca de la paz, no aceptó algunas excepciones que hacían a las condiciones e hizo volver a los mensajeros del tirano para dar cumplimiento a su fórmula sobre el partícular y concluir la paz, si quería, enviando con ellos a su hombre de confianza, Ahmad b. Ya'là para ser observador y corroborador, partiendo todos de vuelta a Yilliqiyya, que Dios destruya, a fines de du-l-qa'da [6 septiembre]. En la conclusión de esto permaneció Ahmad con Ramiro el resto del año 28, partiendo [de León] concluido el tratado, a primeros del siguiente año, 29 [6 octubre 940] ${ }^{50}$.

\section{HASDAY EN LEÓN POR PRIMERA VEZ [941].}

Pero la realidad era que Muhammad b. Hasim de Zaragoza seguía preso en León, en poder del tirano Ramiro hijo de Ordoño, que se aferró a su presa y le marcó subido rescate, no ahorrando an-Nasir esfuerzo para liberarlo, hasta que lo consiguió mediante gran dispendio y refinados $\operatorname{ardides}^{51}$, en clara alusión a Hasday, que es en estas circunstancias cuando hace su aparición en el marco de las relaciones diplomáticas entre 'Abdarrahmán III y Ramiro II, de modo que, aunque irritaban a an-Nasir sus ambages, hasta el punto de pensar en cortar el cable que le había tendido, no obstante, recordando el largo y penoso cautiverio de Muhammad b. Hasim [señor de Zaragoza], movióle su lealtad a condescender en la

\footnotetext{
49 IBN HAYYAN; trad. VigUeRA y CORRIENTE, Crónica del califa, p. 338.

${ }^{50}$ IBN HAYYAN; trad. ID., ibid., p. 344 y p. 345.

${ }^{51}$ IBN HAYYAN; trad. ID., ibid., p. 326.
} 
paz con Ramiro, como medio de liberar con vida a aquél, esforzándose todo lo posible. Por eso mandó a Yilliqiyya al secretario judío Hasday b. Ishaq en yumadà II [3-31 marzo 941], a concluir la paz que se venía tratando y a procurar la liberación de Muhammad b. Hasim, que había estado en poder de Ramiro desde la batalla de Alhándega en el año 27 [6 agosto 939] en prolongado y miserable cautiverio, lo que incitó la compasión y lealtad de an-Nasir a aceptar, por librarlo, grandes concesiones. Mandó, pues, hacia Ramiro a este Hasday, persona sin par en su tiempo entre los servidores por su cultura, habilidad y sutileza, a la que había llamado para que se entrevistara con Ramiro, informándole de sus deseos, que consiguió realizar cuando Dios lo permitió, como se dirá en su lugar ${ }^{52}$.

Sin embargo, las cosas no fueron fáciles en León para un hombre tan hábil, en tantos aspectos, como era Hasday, y lo cierto es que el secretario judío tuvo que desplegar muy a fondo todos sus recursos ante Ramiro II (Hasday fue al tirano, lo sondeó, incitó y se lo ganó con halago) y toda su experiencia (hasta hacerse querer extraordinariamente y escuchar de éste), mediante frecuentes encuentros en su larga estancia de medio año largo junto al monarca (que departía con él a menudo en su prolongada permanencia de 7 meses y días), hasta el punto de que el leonés terminó aficionándose a su compañía (pues agradaba a Ramiro escuchar su conversación y se fiaba de él y le hacía caso), a pesar de la añoranza del judío (sin que Hasday manifestara la angustia que le causaba tan larga estancia y la nostalgia de su patria, sino que por el contrario fingía serle ventajoso prolongarla), de forma que el diplomático califal tardó mucho más de lo previsto en poder afrontar directamente su delicada misión (hasta que logró conocer sus secretos y objetivos y pudo dar un tiro certero en su blanco lejano y difícil, pudiendo tocar el asunto de su cautivo, Muhammad b. Hasim y el remoto objetivo de su liberación); Ibn Hayyan resume diciendo que lo hizo con tan buen resultado que la consiguió prontamente ${ }^{53}$, pero lo cierto es que hubo importantes obstáculos que salvar, según nos informa el propio historiador cordobés. Veamos.

En efecto, comencemos por decir que si Hasday llegó a León en el mes de marzo, parece que a pesar de su habilidad no pudo tocar el asunto de la liberación del zaragozano (dar su tiro certero) hasta mayo, mes en el que Ramiro, complacido sin duda con la compañía del judío cordobés (según se ha visto) tomó una decisión dilatoria, al ordenar que fuese el propio prisionero Muhammad b. Hasim el que escribiera personalmente al califa para solicitar la presencia en León de tres obispos cristianos del califato, condición "sine qua non" (habrá que suponer

52 IBN HAYYAN; trad. ID., ibid., p. 350.

53 IBN HAYYAN; trad. ID., ibid., p. 350. 
necesariamente) para que el rey cristiano abriera las negociaciones relativas a la suma del rescate, que en situaciones anteriores similares había alcanzado la considerable suma de cien mil sueldos de oro ${ }^{54}$. La carta llegó a Córdoba cuando ya corría el mes de junio, y lo cierto es que el califa se apresuró a cumplir la exigencia de inmediato, no sin advertir severamente a los (sin duda sorprendidos) pastores cristianos sobre la necesidad de apoyar unas fructíferas negociaciones: En ramadán [30 mayo - 28 junio] de este año llegó desde Yilliqiyya a an-Nasir carta de Muhammad b. Hasim, pidiéndole enviase a los principales obispos cristianos de al-Andalus para pactar su rescate con el tirano Ramiro, ordenando aquél comparecer al metropolitano 'Abbas b. al-Mundir, obispo de Sevilla, a Ya'qub b. Mahran, obispo de Pechina [Almería], y a 'Abdalmalik b. Hassan, obispo de Elvira [la antigua "Iliberris", Granada], a quienes recibió, una vez reunidos en Córdoba, ordenándoles ir a Yilliqiyya y actuar diligentemente en el asunto: Con este fin salieron... entrando en Yilliqiyya por la parte de Ahmad b. Ya'là, caíd [de la Frontera Media] ${ }^{55}$.

Por fin, una vez hubieron llegado a León en julio los pontífices andalusíes, el asunto de la liberación de Muhammad b. Hasim se trató de forma satisfactoria para la partes, pero tampoco muy rápidamente, pues el tratado de paz fue acordado un mes después, cuando ya transcurría agosto, afectando a todo el territorio de la soberanía de Ramiro II ("Gallaecia" y Castilla) e incluso al reino de Pamplona, según lo transmitido por Ibn Hayyan de Córdoba: En du-l-qa’da [28 julio - 26 agosto] de este año quedó completa la paz con el tirano Ramiro hijo de Ordoño, a quien Dios maldiga, concluyéndola an-Nasir con la delegación enviada entonces por Ramiro a su capital [Córdoba], con las cláusulas que al califa plugo imponerse en solemne acto, como había hecho el tirano en su propia capital [León], habiéndose encargado de su delimitación y ratificación el judío Hasday b. Ishaq que estaba en ésta. Todo concluyó excelentemente, poniéndose fin a la guerra

54 Eso fue lo que pagó el general Hasim ibn 'Abdalaziz para rescatar a su hijo "Abulkasim", prisionero en el palacio de Alfonso III, abuelo de Ramiro II (Crónica Albeldense; trad. MoRAlEJo, Crónicas asturianas, p. 251).

55 Ibn Hayyan; trad. Viguera y Corriente, Crónica del califa, pp. 350-351. Hay una contradicción evidente en el texto (o en la traducción), pues se dice literalmente que los obispos "salieron a mediados de sa'ban (mediados de mayo 941) entrando en Yilliqiyya", lo que se contradice con la llegada carta de Muhammad a Córdoba (solicitando la presencia de los prelados) en el mes de "ramadán" (30 mayo - 28 junio). Así pues, los obispos hubieron de salir de Córdoba, no a mediados de "sa’ban", sino a mediados de "sawwal" (29 junio - 27 de julio), más acorde con los apresurados acontecimientos que se sucedieron: $1^{\circ}$ ) Recepción de la carta (tal vez en la primera quincena de junio); $2^{\circ}$ ) Aviso apresurado (hay que suponer) a los prelados en sus respectivas sedes; $3^{\circ}$ ) Reunión de los tres pontífices en Córdoba; y $4^{\circ}$ ) Partida de la delegación episcopal andalusí hacia León (segunda quincena de julio). 
entre las dos comunidades, desde Santarén a Huesca, pues Ramiro asoció en el tratado al señor de Pamplona, Sancho hijo de García [lege: García hijo de Sancho], a Fernán González, conde de Castilla, a los Banu Gómez [Diego Muñoz de Saldaña] y Banu Ansur [Ansur Fernández de Monzón], y otros importantes condes leoneses, figurando en la paz del tirano Ramiro los nombres de los condes y alcaides de su nación que fueron testigos: El presbítero Ayyub, Mas.r. Soldado, D.nyl soldado, Sa'id b. 'Ubayda, Alvar soldado, ...on soldado, Martín soldado, Salomón soldado, el obispo Julián, el juez Abu Sa'id y otros muchos, a todos los cuales alcance Dios con su maldición e ira ${ }^{56}$.

Ibn Hayyan se limita a mencionar unos cuantos testigos, pero añade que fueron muchos más los que se encontraban presentes en el solemne acto celebrado en la "urbe regia" legionense, probablemente el día 11 de agosto ${ }^{57}$. Y sin embargo, la delegación diplomática cordobesa no abandonó León de manera inmediata a la firma del tratado de paz en agosto de 941: ¿por qué? Tal vez porque Ramiro seguía empeñado en la compañía de Hasday, lo que unido a los preparativos consiguientes, propició en efecto que la embajada no fuera autorizada, por el momento, a partir.

Los dos meses siguientes (del 12 de agosto al 13 de octubre) debieron hacerse eternos para la misión cordobesa, aunque un hombre curioso y culto como Hasday hubo de encontrar sin duda motivos que aminoraran su añoranza y saciaran su gran curiosidad, entre los cuales, naturalmente, la situación de la pequeña o incipiente colonia judía leonesa a la que pertenecía su colega Baruj, cuyos miembros todavía no asomaban a los diplomas, no sabemos si por la falta de costumbre inicial de consignar su condición en los documentos, o porque todavía era reducidísimo el número de sus individuos (o por ambos motivos a la vez) ${ }^{58}$.

56 IBN HAYYAN; trad. ID., ibid., p. 351.

57 Teniendo en cuenta que el tratado se firmó en agosto de 941, según Ibn Hayyan, tomamos como referencia el día 11, fecha de un diploma real en el que se encuentran junto a Ramiro II muchos de los personajes citados a continuación (los dos hijos varones, seis obispos, nobles locales leoneses y alguno gallego), evidente reflejo de la celebración de una magna asamblea plena del palacio, en cuyo transcurso hubo de suscribirse con muchas probabilidades el tratado de paz con Córdoba, despachándose asimismo, como era costumbre, otros muchos asuntos, entre los cuales esta donación real a Celanova que nos sirve de fuente; ed. SÁEZ, E y SÁEz, C. (1996). Colección diplomática monasterio de Celanova (842-1230): 1 (842-942). Madrid: Universidad de Alcalá, doc. 69.

58 Anótese el caso relativamente cercano (entre otros posibles) del hebreo leonés Justo (10191026), que en una carta de 23 de marzo de 1026 es mencionado: "Iuzef et uxor tua Iusta"; ACL, $n^{\circ}$ 1989 y TL, ff. 302v-303r: ed. Ruiz AsEncio, J.M.. (1987). Colección documental del Archivo de la catedral de León (775-1230), III (986-1031). León: Centro de Estudios e Investigación "San Isidoro"; 
Y así hasta que, coincidiendo con la otoñal vendimia leonesa, llegó por fin del palacio leonés la noticia de que Ramiro II había dado la preceptiva autorización para el retorno de la embajada califal a Córdoba, lo que fue inmediatamente comunicado al califa a través de un correo: Llegó a an-Nasir la noticia de la liberación de Muhammad $b$. Hasim at-Tuyibi de su cautiverio y de que venía a palacio, habiendo salido de Yilliqiyya a tierra musulmana el lunes, cuando quedaban 12 noches de muharram [13 octubre], con el secretario Hasday b. Ishaq, embajador del sultán ante el tirano Ramiro, con los obispos cristianos principales que habían concluido con él la paz y otros que se habían reunido entonces en el palacio de Ramiro. La noticia de la llegada de Muhammad y los demás a Córdoba llegó el jueves de 6 de safar [31 octubre], habiendo tenido lugar su captura el martes, quedando 13 noches de sawwal del año 27 [6 agosto 939], de modo que entre éste y el día de su entrada en Córdoba habían transcurrido 2 años, 3 meses y 19 días $^{59}$. De modo que, tanto Hasday como el liberado Muhammad b. Hasim de Zaragoza y los tres obispos cristianos de al-Andalus, con el resto de la comitiva califal y la nutrida legación leonesa que a su vez visitaba Córdoba, tardaron 18 días en llegar a la capital de califato ${ }^{60}$, junto con los regalos de cortesía del rey cristiano, alguno de ellos extremadamente valioso, tanto como para justificar también, por sí mismo, la larga estancia del judío cordobés en la capital leonesa. Veamos.

Podemos estar seguros de que Hasday conocía sobradamente durante su estancia en León la turbación del califa por haber perdido su valioso corán en la batalla de Simancas de 939, un precioso ejemplar dividido en doceavos y muy estimado por él, siendo grande su quebranto y arrepentimiento por haberlo arriesgado llevándolo a territorio enemigo contra su costumbre, por lo que constantemente pedía perdón a Dios, su creador, por aquella falta y ofrecía cualquier cosa por su rescate. Las más de sus partes le habían sido entregadas, salvo unas pocas que los musulmanes no pudieron hallar en Yilliqiyya, lo que redobló su culpa, siguiendo empeñado en buscarlas y revolver todos los rincones

Caja España; Archivo Histórico Dicoesano, doc. 828; mientras que en otra redacción de la misma escritura es traído como "Iuzef ebreo et uxor tua Iusta"; ACL, TL, f. 297v: ed. ID., ibid., doc. 828-B.

${ }^{59}$ IBN HAYYAN; trad. VigUERA y CORRIENTE, Crónica del califa, p. 355.

${ }^{60}$ El período empleado por esta nutrida comitiva armoniza con lo que traen otras fuentes. AlIdrisi nos informa que "de la ciudad de León... a la de Toledo hay siete días" (trad. SAAVEDRA, La geografía de España del Edrisí, pp. 144 y 145). Y es Ibn al-Sabbat quien nos dice que "Toledo está situada al noroeste de Córdoba, separándolas una distancia de siete días para un jinete diestro"; trad. De Santiago Simón, E. (1973). "Un fragmento de la obra de Ibn al-Sabbat (s. XIII) sobre alAndalus". Cuadernos de Historia del Islam, 5, p. 57. 
tras ellas, con lo que resulta más que probable, aunque no lo diga expresamente Ibn Hayyan, que fuese el propio Hasday el que sutilmente advirtiera al monarca leonés sobre la conveniencia y las ventajas que obtendría con la devolución de las partes que todavía faltaban del referido corán, hasta que el tirano Ramiro las halló en un rincón de Yilliqiyya y se las mandó [al califa], siendo entonces completa su alegría, tras haber gastado gran suma en el rescate de su corán, pues en efecto, según añade el historiador cordobés, con el liberado Muhammad b. Hasim vino el... embajador del señor de Yilliqiyya, Ramiro hijo de Ordoño... con un regalo para an-Nasir y para su hijo y heredero al-Hakam, del que formaban parte 30 prisioneros musulmanes que tenía y las restantes partes que faltaban del corán de an-Nasir, perdido en Yilliqiyya... lo que fue para éste la parte preferible del regalo, ya que con ello le devolvía Dios la conservación de todas las partes de este alcorán, a causa de lo cual temía la divina censura, hasta recobrarlas, de forma que a este presente del bárbaro Ramiro correspondió con creces [el califa] contento de haber rescatado el libro divino, como hizo también su hijo al-Hakam, despachando a su embajador en unión de Ya'far b. Yahyà b. Mdm para entrevistarse con el bárbaro Ramiro según sus instrucciones... a fines de rabi' II [21 enero 942 ${ }^{61}$.

Aunque la paz fue poco duradera, pues había pasado más que medio año cuando Ramiro hijo de Ordoño conoció la aparición de los turcos en la Marca de Lérida y el pavor de los musulmanes de aquella zona, con lo que pretendió aprovecharse, violando las promesas a que se había comprometido solemnemente ante obispos y monjes $^{62}$.

\section{HASDAY EN LEÓN POR SEGUNDA VEZ [956].}

Durante los años siguientes, Hasday siguió prestando importantes servicios al califa. Según Ibn 'Idari en el año 334 H. [13 agosto 945 - 2 agosto 946] 'Abdarrahmán III vio llegar a los embajadores del gran emperador de los romanos, Constantino, hijo de León, señor de Constantinopla, esto es, el emperador Constatino VII Porfirogénito (945-969), cuyos legados volvieron en 338 H. [1 julio 949 - 20 junio 950] para ofrecer el establecimiento de relaciones amigables y correspondencia regular... entregaron la carta de su soberano, la cual estaba escrita con letras de oro sobre pergamino con tinta azul; ella llevaba un sello.... y sobre una de sus caras la efigie del Mesías (;sobre Él sea la paz!), y

\footnotetext{
${ }^{61}$ IBN HAYYAN; trad. VigUERA y CORRIENTE, Crónica del califa, p. 356-357.

${ }^{62}$ IBN HAYYAN; trad. ID., ibid., pp. 361-363.
} 
sobre la otra las efigies del emperador Constantino y de su hijo ${ }^{63}$. Según el médico contemporáneo Ibn Yulyul (943-994), se trataba de una carta acompañada de presentes de gran valor, entre los cuales se encontraba el tratado de Dioscórides... iluminado con magníficas miniaturas griegas y escrito en griego, por lo que el monarca bizantino aclaraba en su escrito que no se podría «obtener provecho de el Dioscórides más que con un traductor avezado en el griego y que conozca las propiedades de esas drogas. Si tienes en tu país a alguien que reúna estas dos condiciones sacarás, oh Rey, la mayor utilidad de este libro».

Pues bien, según el repetido Ibn Yulyul, que llegó a conocer personalmente a Hasday, entre los cristianos de Córdoba no había nadie capaz de leer el griego... [y] en consecuencia el libro de Dioscórides se quedó en la Biblioteca de 'Abd alRahman an-Nasir sin ser traducido al árabe: estaba en al-Andalus, pero sus habitantes utilizaban la traducción de Esteban procedente de Bagdad, incompleta y de poca calidad, de modo que, cuando el califa contestó al emperador bizantino, le pidió que le enviase a alguien que hablara el griego y el latín para que enseñara estas lenguas a sus esclavos, que así se transformarían en traductores. En efecto, Constantino le envío entonces a un monje llamado Nicolás, que llegó a Córdoba en el año 340 [= 9 junio 951 - 20 mayo 952], añadiendo que en la capital del califato había por ese entonces una serie de médicos que investigaban, indagaban y buscaban con avidez el modo de determinar los nombres de los simples que figuraban en el Dioscórides, entre los cuales el más interesado y diligente entre todos estos médicos era el judío Hasday b. Saprut, quien así procuraba complacer a 'Abdarrahmán al-Nasir. El monje Nicolás pasó a ser para él la persona más íntima y apreciada. Así pudo comentar los nombres de los simples del libro de Dioscórides que aún eran desconocidos. Fue el primero que fabricó en Córdoba la teriaca llamada faruq, determinando las plantas que entran en su composición ${ }^{64}$.

Pero además, Hasday tuvo también una faceta que podemos llamar de "geógrafo", como consecuencia de las investigaciones que afanosamente afrontó al llegarle noticias sobre el lejano reino de los judíos jazares, situado, en palabras de Del Valle, "a ambas márgenes del bajo Volga, entre el mar Caspio y Crimea y el Cáucaso sur"65. Unas noticias que según el propio Hasday le causaron una extraordinaria sorpresa y un interés enorme por documentarse al respecto en los libros de los $\operatorname{sabios}^{66}$. Y luego, sabemos que intentó remitir la carta al rey de

63 IBN 'IDARI; trad. ARJONA CASTRO, A. (1982). Anales de Córdoba musulmana, 711-1008. Córdoba : Monte de Piedad y Caja de Ahorros de Córdoba, pp. 104 y 105-106.

${ }^{64}$ IBN YULYUL; trad. VERNET, Los médicos andaluces, pp. 447-448.

${ }^{65}$ Vid. Del VAlle, La Escuela Hebrea de Córdoba, p. 339, n. 31.

${ }^{66}$ Carta de Hasday a los Jazares; trad. ID, ibid., p. 333 y p. 334, n. 36. 
Jazaria aprovechando la partida de la embajada califal que el 24 de octubre de 949 fue recibida en Bizancio por Constantino VII Porfiriogénito ${ }^{67}$, a través de un legado que el propio Hasday equipó y envió, llamado Isaac ben Natán (se ofreció voluntario a llevar mi carta... le di una gran remuneración... y todas las expensas del viaje... de mi peculio particular envié también un soberbio regalo al rey de Constantinopla rogándole que ayudara a este enviado mío), aunque una vez allí todos los andalusíes fueron retenidos por el emperador durante aproximadamente seis meses, tras lo cual, dice Hasday, hizo también volver a mi enviado con una carta en la que se decía que el camino que mediaba entre ellos y los jazares era peligroso... cuando escuché la mala noticia me encolericé hasta ponerme malo de morir, pero no se rindió, y proyectó un nuevo contacto vía Jerusalén, la ciudad santa, debido a que unos israelitas me garantizaron llevar la carta desde el país de Nísibe [Mesopotamia], desde allí a Armenia, y de aquí por fin a Jazaria, aunque en ese entretanto fue cuando se produjo la llegada a Córdoba en 953 de los embajadores del rey de los gábalos (germanos) y con ellos dos israelitas... Saúl y... Yosef. Cuando estos conocieron mi desazón me consolaron y me dijeron: «danos tu carta que nosotros la llevaremos al rey de los gábalos, el cual por su honor, la enviará a los israelitas que residen en el país de los Húngaros. Estos, a su vez, la enviarán a Rusia y de allí a Bulgaria hasta que llegue tu carta, según tu deseo al lugar que quieres» ${ }^{68}$, lo que al fin fue posible gracias precisamente a un judío alemán llamado Jacob ben Eliazar, según consta en la respuesta del jázaro Yosef, rey... a... Hasday, cabeza de la golá, ben Ishaq ben Ezra, español, caro para nosotros y honrado entre nosotros. Te comunico que nos ha llegado a nosotros tu carta honorable a través de R. Jacob ben Eliazar, del país de Nemes [Alemania]. Nos alegramos con ella y nos regocijamos de tu inteligencia y sabiduría. Encuentro descrita en ella la situación de tu país... ruegas que te dé a conocer la verdad de las cosas, nuestro reino... También deseas conocer la extensión de nuestro país... si es posible que embajadores de nuestra tierra lleguen a vuestro país para que saluden a vuestro querido y eximio rey [...] En tu carta mencionas tu deseo de verme. También yo deseo y quiero sobremanera conocerte, contemplar el extraordinario brillo de tu sabiduría y grandeza. Ójala se realice todo según tu palabra y merezca asociarme a ti, ver tu faz venerable y sumamente apreciada. Tú serás para mí padre y yo seré para ti hijo. Conforme a tu boca se doblegará mi

67 Vid. MAtesanz Gascón, R. (2004). Omeyas, bizantinos y mozárabes : En torno a la "prehistoria fabulosa de España" de Ahmad al-Razi. Valladolid: Universidad, p. 153.

${ }^{68}$ Carta de Hasday a los Jazares; trad. Del VAlle, La Escuela Hebrea de Córdoba, pp. 339-341, n. 56. 
pueblo entero y conforme a tu palabra y consejo certero me regiré yo mismo. Saludos muy cordiales ${ }^{69}$.

Cabe deducir, pues, que Hasday había adquirido una idea bastante aproximada sobre la ubicación del lejano reino judío, suficiente, en todo caso, como para pensar con Del Valle que probablemente se produjo un intercambio mutuo de información entre él y el explorador oriental Ibn Hawkal, en cuya obra aparece inserta sobre uno de sus mapas orientales la siguiente nota: Esta montaña es enorme y extensa. Dijo de ella Hasday ibn Ishaq que se une con los montes de Armenia, que divide la tierra del Rum [el emperador constantinopolitano] y se llega por ella hasta Jazaria y los montes de Armenia. Él conocía estas tierras, porque había viajado por ellas y se había encontrado con sus reyes y habitantes ${ }^{70}$. Una frase, esta última, que en realidad se refiere, no a los viajes orientales de Hasday, inexistentes, desde luego, sino a sus reiterados intentos para contactar con los jazares entre 949 y 953, fechas entre las que habrá que situar, pues, el conocimiento personal entrambos hombres (secretario judío y geógrafo musulmán), sincrónico con la llegada a la península de Ibn Hawkal, que él mismo sitúa a comienzos del año 337 [=948 $]^{71}$.

Pero las relaciones de Hasday con León todavía no habían terminado, pues el destino le tenía reservado todavía al brillante funcionario judío un segundo viaje a la "urbe regia". Por desgracia, el tomo V del "Muqtabis" del Ibn Hayyan se interrumpe a comienzos del 942, de modo que es difícil saber (sin esta fuente) qué camino tomaron las relaciones diplomáticas entre León y Córdoba durante la siguiente década (hasta la muerte de Ramiro II en 951), que posiblemente tuvieron continuidad, a pesar de los indudables conflictos fronterizos que constan en 947 (llegó una carta... anunciando la victoria sobre los habitantes de Galicia $^{72}$ ) y en

${ }^{69}$ Carta del rey jazar, Yosef, a Hasday; trad. ID, ibid., pp. 347-358, vid. etiam n. 4: "Nemes, apelativo usado por eslavos, húngaros y árabes para denominar a Alemania".

70 IBN Hawkal; vid. M.J. Romani Suay, M.J. (1971). Configuración del Mundo. Valencia (Textos Medievales, 26), p. 333 n. 36.

${ }^{71}$ IBN HAWKAL; trad. ID, ibid., p. 60. Este mismo autor (ibid., p. 62) constata que "Un artículo de exportación muy conocido consiste en los esclavos, muchachos y muchachas, que han sido tomados de Francia [condados catalanes] y Galicia [Yilliqiyya = "Gallaecia" = reino de León], así como los eunucos eslavos. Todos los eunucos eslavos que se encuentran sobre la superficie de la tierra provienen de España. Se les hace sufrir la castración cerca de este país; la operación es hecha por comerciantes judíos". Según Dozy, R. (1982). Historia de los musulmanes de España, III. Madrid: Turner, p. 61: "Al principio, el nombre de eslavos se aplicaba a los prisioneros que los pueblos germánicos hacían en sus guerras, contra las naciones así llamadas, y que vendían a los sarracenos españoles; pero con el transcurso del tiempo... se dio este nombre a todos los extranjeros que servían en el harén o en el ejército, cualquiera que fuese su origen".

${ }^{72}$ IBN 'IDARI; trad. ARJONA, Anales de Córdoba musulmana, p. 105. 
950 (an-Nasir envió a su caíd Ahmad b. Ya’là contra Galicia ${ }^{73}$ ), el mismo año que Ramiro II atacó Talavera (Talabira) de la Reina: Reunido ejército, avanzó para destruir la ciudad de agarenos que ahora por el pueblo es llamada Talavera... y volvió a su propia tierra con victoria ${ }^{74}$.

Bajo el punto de vista de la situación fronteriza, la situación no había cambiado mucho durante el comienzo de su hijo y sucesor Ordoño III (951-956), pues sabemos que en $341 \mathrm{H}$. [= 29 mayo 952 / 18 mayo 953] los musulmanes hicieron contra los cristianos una campaña en la que quedaron varias veces victoriosos ${ }^{75}$. Desconocemos cualquier detalle sobre estas victorias cordobesas, y hasta es probable que el nuevo y joven monarca leonés solicitara la paz, y que con este motivo visitaran León por ese mismos años (952-954) dos significados personajes andalusíes, uno musulmán y otro cristiano: Mudarrafe filius Abumar [Mutarrif b. Abu 'Umar] y Martinus abba Cordouensis ${ }^{76}$.

Y mientras tanto, graves acontecimientos (que también afectaron de algún modo a Hasday) iban a producirse entre el califa y el monarca alemán Otón I el Grande (936-973), restaurador al cabo del Sacro Imperio Romano Germánico. Según Simonet:

“Abderrahmán andaba en negociaciones con... Otón I, con motivo... de los destrozos causados por los moros españoles que, anidados en Fraxinetum, sobre el golfo de Saint-Tropez (enclave en la costa mediterránea), infestaban los dominios de aquel monarca, sobre todo por la parte de Italia. A consecuencia de sus reclamaciones, Abderrahmán envió en 950 a Otón una embajada a cuya cabeza iba cierto obispo mozárabe, cuyo nombre y sede ignoramos. Sólo sabemos haber muerto en la corte de Alemania durante su

73 IBN 'IDARI; trad. francesa FAGNAN, E. (1904). Histoire de l'Afrique et de l'Espagne intitulée alBayano 'l-Mogrib, II. Alger : Gouvernement General de l'Algerie, p. 360.

74 SAMPIRO, Crónica; trad. GÓMEZ-MORENo, Introducción a la Historia Silense, p. CV. En esta misma época, el 25 de agosto de 951, el conde Jimeno Díaz y su mujer Adosinda Gutiérrez (primahermana de Ramiro II) hacen una extensa donación al monasterio de Celanova, consistente, entre otros bienes, en una corte en el arrabal de la ciudad de Coimbra, que habían comprado a unos inconcretos judíos "in Kires": "Scemenus [Didaci] et Adosinda [Gutierrici]... in arraualde de ciuitate Colimbria corte cum domus et intrinsecis siue et uineas que emimus de iudeos in Kires"; ed. SÁEZ, E y SÁEz, C. (2000). Colección diplomática monasterio de Celanova (842-1230) : 2 (943-988). Madrid: Universidad de Alcalá, doc. 91.

${ }^{75}$ IBN 'IDARI; trad. FAGNAN, Histoire de l'Afrique et de l'Espagne, p. 362: "Les musulmans firent contre les chretiens una campagne ou ils resterent plusieurs fois victorieux".

76 ACL, TL, ff. 388v-389r, sin año; ed. SÁEZ, E y SÁEZ, C. (1990). Colección documental del archivo de la catedral de León (775-1230), II. (953-985). León: Centro de Estudios e Investigación "San Isidoro"; Caja España; Archivo Histórico Dicoesano, doc. 276, en 937-954. 
misión, que se dilató demasiado, porque las letras... estaban escritas en un estilo musulmán que pareció injurioso... fueron mal recibidas... y los embajadores quedaron retenidos por espacio de tres años. Al cabo de este tiempo, Otón resolvió enviar a Córdoba una embajada, y con ella una respuesta merecida... escrita por Bruno, hermano de Otón, sabio arzobispo de Colonia, y su portador fue un monje del convento de Gorze, en la Lorena, llamado Juan... y... otro monje llamado Garamanno... y ambos llegaron a Córdoba por los años 954... y... el despacho de esta embajada fue muy lento y difícil. Abderrahmán, enterado del contenido de las letras, ofensivo a la secta mahometana, quiso recibir al embajador sin ellas... y... pasados en esto algunos meses, Abderrahmán le envió un obispo mozárabe llamado Juan, probablemente el que regía a la sazón la diócesis de Córdoba, el cual quiso persuadirle a que se presentase al sultán solamente con los regalos... ambos conversaron largamente... pero el de Gorze se negó resueltamente a presentarse al sultán sin las letras que traía",77.

Nada dice el gran historiador de los mozárabes sobre la intervención en el asunto del judío Hasday, de quien el legado Juan de Gorze llegó a decir "que nunca había visto ni oído a hombre más sagaz" (iudeum quondam, cui nomen Hasdeu, quo neminem unquam prudentiorem se uidisse aut audisse nostro testati sunt), aunque sabemos que, oficiando una vez más como hábil diplomático, Hasday también advirtió en 954 con sincera preocupación a los embajadores imperiales sobre el riesgo gravísimo que corrían al entregar al califa la carta ofensiva para la religión mahometana que traían: Es peligroso presentarse con esto al rey. Tened sumo cuidado con lo que respondáis a los mensajeros del rey. Como no dudo que conocéis la severidad de la ley, conviene que reflexionéis y no la quebrantéis ${ }^{78}$. Pero ya sabemos que el embajador alemán se negó en rotundo a entregar únicamente los regalos, y el califa no vio otra solución que retener en Córdoba a la representación extranjera mientras enviaba a su vez una embajada amistosa a Alemania, presidida por un hábil cristiano ansalusí llamado Recemundo, que antes de su partida en la primavera de 955 fue premiado por 'Abdarrahmán con la silla episcopal de Elvira ("Illiberris", Granada) ${ }^{79}$.

Entretanto, Ordoño III deshacía en 954 una peligrosísima conjura nobiliaria en favor de su hermanastro Sancho el Gordo, apoyada por la abuela de éste, Toda de Pamplona, y por Fernán González de Castilla, suegro del propio rey Ordoño, un

\footnotetext{
77 Vid. Simonet, F.J. (1983). Historia de los mozárabes de España, III. Madrid: Turner, pp. 607608.

${ }^{78}$ Vita Ioannis abbatis Gorziensis auctore Ioanne abbate S. Arnulfi; vid. DEL VALLE, La Escuela Hebrea de Córdoba, p. 70 y p. 71, n. 109.

${ }^{79}$ Vid. SimOnET, Historia de los mozárabes de España, p. 610.
} 
monarca muy enérgico, a pesar de su juventud, que estuvo bastante activo, y defendió sus ciudades, y vindicó el cetro del reino, volviéndose a sus propias tierras los susodichos; y tras aplastar otro levantamiento de algunos condes gallegos en 955 (reunido gran ejército, domeñó a Galicia), se lanzó resueltamente contra la lejana Lisboa: Ciertamente, el mismo Ordoño... domeñó a Galicia, saqueó Lisboa y llevó consigo muchos despojos juntamente con cautivos, y volvió a la corte real (de León) con paz y victoria ${ }^{80}$. Y fue en estas circunstancias cuando ambas cortes hispanas buscaron un interesado mutuo acercamiento, cuya iniciativa parece que partió de León: En el año 344 [H. = 25 abril 955 / 14 abril 956] llegó el emisario de Ordoño hijo de Ramiro... habiendo enviado Ordoño a su delegado para gestionar la paz, que an-Nasir le acordón ${ }^{81}$.

Por desgracia desconocemos cualquier detalle relativo a este contacto diplomático, pero la coyuntura era lo suficientemente provechosa para la corte de Córdoba como para que 'Abdarrahmán III (ocupado por entonces en graves asuntos africanos) ordenara la partida hacia León de sus propios embajadores, encabezados por el médico Muhammad b. Husayn (Abu-l-Walid Muhammad b. Husayn, más conocido por al-Kittani, vivió hacia el fin del reinado de an-Nasir, a quien sirvió como médico, y al principio del reinado de al-Mustansir -Alhakam II-. Era un hombre brillante, magnánimo, de dulce palabra, noble; amado por el vulgo y la corte por su generosidad científica y su entrega -a los enfermos-. No era hombre que buscara dinero ni intentara reunirlo. Era amable en el trato con los enfermos, sabio experimentado ${ }^{82}$ ) y por el mismísimo Hasday, lo que nos da una idea sobre la importancia que el califa otorgó a tales conversaciones y lo que esperaba obtener de ellas, cuando ya corría el año 345 H. [= 15 abril 956 / 4 abril 957], tal vez en la primavera de 956: Muhammad b. Husayn, que había sido enviado por an-Nasir en embajada ante el rey cristiano de Galicia [Yilliqiyya = "Gallaecia"], Ordoño hijo de Ramiro, volvió en compañía del judío Hasday ben Saprut, portador de una carta solicitando la paz. La propuesta negociada por Hasday fue analizada por 'Abdarrahmán III y por su heredero al-Hakam, y tras imponer su criterio en diversos aspectos contenidos en las cláusulas, despidió a los embajadores cristianos, que regresaron a León para informar a su vez a Ordoño III (el emir consintió, con el consejo de su hijo al-Hakam, a esta petición, pero imponiendo diversas condiciones que los mensajeros del príncipe cristiano

\footnotetext{
${ }^{80}$ SAMPIRO, Crónica; trad. GÓMEZ-MORENO, Introducción a la Historia Silense, pp. CV-CVI.

${ }^{81}$ IBN JALdUn; trad. MACHAdO Mouret. O.A. (1967). Cuadernos de Historia de España, 45-46,

${ }^{82}$ IBN YULYUL; trad. VERNET, Los médicos andaluces, p. 460.
} p. 392. 
transmitieron a su señor ${ }^{83}$ ), quien, según sabemos, llegó a solicitar a su vez la inclusión en el acuerdo de paz de su suegro el conde castellano, finalmente sometido ya (queriendo o no queriendo, dice Sampiro ${ }^{84}$ ) a su autoridad: En el año 345 mandó pedir la inclusión de Fernán González conde de Castilla... y an-Nasir accedió a lo solicitado por Ordoño hijo de Ramiro ${ }^{85}$. Todo lo cual cuadra muy bien con la presencia de Fernán González en la corte leonesa el 5 de mayo de 956, junto a su yerno y su hija (Hordonius serenissimus princeps... Hurraca regina... Fredenandus Gundesalviz comes $\left.{ }^{86}\right)$.

\section{HASDAY, MÉDICO DE SANCHO DE LEÓN [958].}

Hasday, que sepamos, no volvió más a León, pero no por ello perdió el contacto con los reyes leoneses. Todavía le quedaba una importante misión. En efecto, tras la inesperada muerte del joven Ordoño III en septiembre/octubre de 956, el trono fue heredado por su ambicioso hermanastro Sancho el Gordo, que en 957 fue depuesto a su vez por los partidarios de su primo Ordoño IV el Malo, el cual hizo su entrada en la capital del reino el 1 de agosto de 958, no sin vencer la resistencia del noble Froila Vela, apoyado por algunos contingentes cordobeses, probablemente fronterizos (la entrada... del rey don Ordoño, serenísimo príncipe, hijo de Alfonso... en la urbe regia después que pusiera en fuga a los moros que vinieron con Fruela Vigilaniz ${ }^{87}$ ), de modo que según Sampiro, el rey Craso se tuvo que refugiar una vez más en la corte pamplonesa (cumplido el primer año de su reinado, por cierto ardid del ejército, tramada conjura, saliendo de León llegó a Pamplona), donde su vieja abuela materna, la reina Toda, no dudó en solicitar auxilio a su hermano uterino 'Abdarrahmán III, de forma similar a como había hecho ya un cuarto de siglo antes, en 934, curiosamente el mismo año en que había nacido el propio Sancho: Le llegaron mensajeros de la taimada Toda, hija de Aznar que se acogía a la obediencia e invocaba los vínculos de sus antepasados con los del califa, pidiéndole que le concediera la paz... an-Nasir le impuso a

83 IBN 'IDARI; trad. francesa FAGNAN, Histoire de l'Afrique et de l'Espagne, pp. 366-367: "Mohammed ben Hoseyn, qui avait été envoyé par En-Naçir en ambassade auprès du roi chrétien de Galice Ordoño ben Rodmir, revint en compagnie du juif Hasday ben Chebroût, porteur d'une lettre demandant la paix. L'émir acquiesça, avec l'aveu de son fils El-Hakam, à cette requête, mais en imposant diverses conditions que les messagers du prince chrétien transmirent à leur maître".

${ }^{84}$ SAMPIRO, Crónica; trad. GÓMEZ-MORENO, Introducción a la Historia Silense, p. CVI.

${ }^{85}$ IBN JALDUN; trad. MACHADO MOURET, p. 392.

${ }^{86}$ ACL, no 908; ed. E. SÁEZ y C. SÁEZ, Colección catedral de León, II, doc. 295.

87 Ed. Mínguez FeRnÁnDEZ, J.M. (1976). Colección diplomática del monasterio de Sahagún (siglos $I X$ y X). León: Centro de Estudios e Investigación "San Isidoro"; Caja España; Archivo Histórico Dicoesano, doc. 159. 
cambio que viniera a visitarlo... como prueba de buena intención, dándole para ello salvoconducto, lo que se apresuró a hacer en unión de sus más notables hombres, condes y obispos... con un buen regalo. An-Nasir ordenó que, a su entrada, se colocara el ejército en formación y equipo de gala, lo que ella contempló sobrecogida... ella le rindió los honores apropiados y expuso humildemente sus peticiones... siendo bien acogida y agasajada por an-Nasir, que hizo con ella y sus condes un pacto... que estimulaba su completa sumisión y su desentendimiento de los restantes reyes cristianos, aliados, parientes, etc... concluido el tratado que se hizo jurar a los bárbaros, an-Nasir... dio en investidura al hijo de la reina, García hijo de Sancho, el vascón, Pamplona y sus distritos, regalándole a ella y a sus acompañantes abundantes presentes y vestidos que agradaron a todos ${ }^{88}$.

La historia volvía a repetirse 24 años después, aunque ahora, iniciada ya la decadencia leonesa, el califa veía también la ocasión de convertirse en el árbitro indiscutible de la política peninsular, de modo que decidió confiar a Hasday una delicadísima misión, consistente en lograr (como médico) la curación de la enorme obesidad del depuesto rey leonés (ciertamente, como estuviese demasiado gordo, los mismos agarenos le dieron una yerba y quitaron de su vientre la gordura), y luego (como diplomático) que tanto su anciana hermana vascona, como su hijo el rey García Sánchez de Pamplona, y su nieto, el desterrado Sancho Ramírez leonés, viajaran a Córdoba (al rey Sancho... se le exhortó a ir al rey cordobés Abderrahmán ${ }^{89}$ ).

He aquí lo escrito por el insigne Dozy al respecto de la importante intervención del competente Hasday:

“Abderramán... no hubiera podido hacer mejor elección. Hasdai reunía en sí todas las cualidades necesarias para una misión semejante; hablaba muy bien la lengua de los cristianos, era a la vez médico y hombre de Estado, todo el mundo alababa su ingenio, su talento, sus conocimientos, su gran capacidad, y... en cuanto hubo llegado a Pamplona, el judío se ganó la confianza de Sancho, encargándose de medicinarle y prometiéndole una pronta curación. Le dijo que... el califa... exigía la cesión de diez fortalezas, y Sancho prometió entregárselas en cuanto estuviera restablecido en el trono. Mas esto no era todo. Hasdai tenía también el encargo de arreglárselas de modo que Tota fuera a Córdoba acompañada de su hijo y de su nieto. El califa quería satisfacer su vanidad y dar a su pueblo el espectáculo... de que

\footnotetext{
${ }^{88}$ IBN HAYYAN; trad. VigUera y CORRIENTE, Crónica del califa, p. 252.

${ }^{89}$ SAMPIRO, Crónica; trad. GÓmEZ-MORENO, Introducción a la Historia Silense, p. CVI.
} 
una reina y dos reyes cristianos vinieran humildemente a postrarse a sus pies... esta parte de la misión de Hasdai era, pues, la más delicada y la más espinosa... era preciso un tacto y una habilidad de todo punto extraordinarios. Pero Hasdai tenía reputación de ser el hombre más diestro de su tiempo, y la justificó. La orgullosa navarra... dio al fin su consentimiento al viaje propuesto por el judío... a Córdoba, con García y con el desdichado Sancho, cuya salud no estaba aún bastante mejorada y marchaba apoyándose en Hasdai" $"$.

En efecto, los reyes cristianos fueron muy bien recibidos en Córdoba: Tota hija de Aznar, reina de los vascones.. se había empeñado en solucionarle [a su nieto]... la situación, con cuyo propósito fue a entrevistar a an-Nasir... prosternándose ante él para pedirle el otorgamiento de la paz en favor de ella y de ... el rey Sancho hijo de Ramiro, a quien el califa le prestó su apoyo. (Lo mismo) con... García, hijo de Sancho... para sostenerlo en su reinado, defendiéndolo de sus enemigos ${ }^{91}$. Como añade Dozy, "si este espectáculo era grato para la vanidad nacional de los musulmanes, lo era también, y acaso más todavía, para el amor propio de los judíos, porque aquél a quien era debido (Hasday) era un hombre de su religión. Así pues, sus poetas celebraron a porfía su regreso" ${ }^{92}$. Y eso fue lo que hizo precisamente el poeta judío contemporáneo Dunas b. Labrat ha-Levi:

Compón un poema de alabanza / en honor del Príncipe, Jefe de la Academia, / que destruyó totalmente las fuerzas extranjeras, / Está ceñido de gloria y majestad / revestido de ayuda divina. / A los insolentes arrebató diez fortalezas / e hizo una gran poda / entre cardos y espinos. / Trajo al hijo de Ramiro, / a príncipes y sacerdotes. / A un señor, caballero y rey, / lo trajo como un peón, / bastón en mano, / a un pueblo enemigo suyo; / arrastró también a la simple, / la anciana Toda, / que revestía realeza / como los varones, / con la fuerza de su sabiduría, / con el poder de sus argucias, / con la multitud de sus estratagemas, / con la dulzura de sus palabras ${ }^{93}$.

90 Vid. Dozy, Historia de los musulmanes de España, III, pp. 80-81. Vid. R.H. ELía (2006), "Dioscórides rescatado por los andalusíes". Estudios de Historia de España, VIII, p. 90, n. 5, y p. 92, n. 6: "Sancho I el Craso... buscaba el apoyo de Abd ar-Rahmán para recuperar su reino y los servicios médicos de Hasdai y de Abulcasis para curarse de su gordura (...) Entre los más importantes cirujanos musulmanes de la época clásica se encuentra Abul Qasim Jalaf Ibn al-Abbas al-Zahraui, también conocido como Abulcasis, quien nació en 936 (...) Merece atención especial el tratamiento descrito en el Anexo del Tasrif de Abulcasis mencionado para la obesidad mórbida".

${ }^{91}$ IBN JALDUn; trad. MACHADO MOURET, pp. 392-393.

${ }^{92}$ Vid. Dozy, Historia de los musulmanes de España, III, pp. 80-81.

${ }^{93}$ Vid. Peláez Del Rosal, Hasday ibn Saprut en la corte de Abderramán, p. 72. 
Finalmente, con la ayuda del ejército cordobés Sancho salió para su capital (habiendo huido a tierra de moros, regresó con un ejército de paganos ${ }^{94}$ ), y una vez trazado su plan con los generales cordobeses, con su tío García de Pamplona y con sus propios partidarios leoneses (entre los cuales cabe suponer al citado Froila Vela) consiguió entrar en León a comienzos de 959 y desplazar a su primo Ordoño: Tomó consejo de los sarracenos sobre cómo llegaría al reino quitado para sí, del que había sido arrojado. Salió con innumerable ejército, avanzando hacia León... y... Ordoño, huyó y entró en Asturias y perdió el reino. Él lo perdió, Sancho lo recibió. Entrando en León, sometió todo el reino de sus padres ${ }^{95}$.

Sabemos que Sancho le envió a an-Nasir su agradecimiento por el gesto que había tenido para con él, y que el califa por su parte no cesó de favorecerlo con su amistad y ayuda, hasta que falleció (año 961) ${ }^{96}$. Pero lo cierto es que el rey Craso no hubo de mostrarse muy activo en el cumplimiento de todas las cláusulas pactadas con el califa en 958 a través de Hasday, sin sospechar que su primo y oponente Ordoño IV, una vez expulsado de su primer refugio asturiano (en 960), y luego de Castilla por Fernán González (en 962), no tuvo otra alternativa que viajar a su vez a Córdoba (echado de Asturias, llegó a Burgos... expulsaron al mismo de Castilla y lo enviaron a tierra de sarracenos ${ }^{97}$ ), a fin de solicitar ahora en su favor la ayuda militar necesaria al que ya era nuevo califa al-Hakam II (961-976), quien recibió al destronado Ordoño el 8 de abril de 962 en una solemne audiencia (Hakam recibió la visita de Ordoño hijo de Alfonso el Jorobado... en lucha con su primo paterno Sancho ${ }^{98}$ ), en la que sin duda hubo de estar presente Hasday:

Al-Hakam mostró interés por ver al cristiano y se hicieron inmediatamente los preparativos para la ceremonia. Se equipó a las tropas como para la guerra y se vistió espléndidamente a la guardia eslava. Se ordenó a los ulemas, teólogos, secretarios y poetas que aparecieran en el salón de las audiencias, mientras se avisaba a los visires y altos funcionarios del estado para que estuvieran en sus puestos a la hora señalada [...] alHakam guardó silencio algún tiempo, para dar ocasión a Ordoño a serenarse y a sentarse, y cuando notó que el cristiano se había repuesto algo (de su emoción), rompió el silencio y dijo: «Bien venido seas a nuestra corte, Ordoño. Ojalá veas cumplidos tus deseos y realizadas tus esperanzas.

\footnotetext{
${ }^{94}$ Documento de Odoyno; trad. PRIETO PRIETO, El reino de León hace mil años más o menos, p.

95 SAMPIRO, Crónica; trad. GÓMEZ-MORENO, Introducción a la Historia Silense, p. CVI.

${ }^{96}$ IBN JALDUN; trad. MACHADO MOURET, p. 393.

97 SAMPIRO, Crónica; trad. GÓMEZ-MORENO, Introducción a la Historia Silense, p. CVII.

${ }^{98}$ IBN 'IDARI; trad. francesa FAGNAN, Histoire de l'Afrique et de l’Espagne, p. 388.
} 74. 
Encontrarás en nosotros el mejor consejo y la más cordial acogida y mucho más de lo que esperas». Cuando el intérprete explicó a Ordoño el sentido de estas benignas palabras, se reflejó en su rostro la alegría [...] volvió con los leoneses... al palacio que les servía de morada. Poco después le enviaron, para que lo firmase, un tratado 99 .

En ese entretanto, en León se mantenía un importante contingente de tropas pamplonesas en apoyo de Sancho, mandadas por su primo materno, el vascón Ramiro Garcés, que se documenta el 20 de enero de 962 (Ramirus Garseani prolis et provintie Pampilonie ${ }^{100}$ ) y el 16 de marzo de 962, junto a varios de sus hombres, militares y clérigos (Ranimirus prolis Garseani Pampilonie; Furtunius Garseani; Belascus Belasci Pampilonie presbitero; Belascus Furtuni; Lupus Garseani ${ }^{101}$ ), coincidiendo con la llegada a la "urbe regia" de una nueva embajada cordobesa que se volvió en abril/mayo tras arrancar al rey Sancho (preocupado sin duda por la estancia de su rival en Córdoba) el cumplimiento de todos sus compromisos y su amistad, transmitida a través de sus propios embajadores: Llegaron a Córdoba los enviados de Sancho hijo de Ramiro, que estaba en desacuerdo con el príncipe infiel de Galicia [Yilliqiyya], Ordoño, su primo paterno. Estas gentes, entre los que estaban [de regreso] 'Abdarrahmán ben Yahhaf, cadí de Valencia, y Ayyub b. at-Tawil, llegaron en rabi' II [mayo], transmitieron a [al-Hakam II] al-Mustansir la carta por la cual Sancho ben Ramiro le respondía que él y todos sus súbditos reconocerían la autoridad del Príncipe de los creyentes ${ }^{102}$. De modo que, finalmente, el califa decidió mantenerse en la línea de conducta de su padre anNasir para con Sancho y accedió a reconocerlo bajo ciertas condiciones, entre las cuales estaba la de demoler las fortalezas y las torres que se hallaban cerca de las fronteras de los musulmanes ${ }^{103}$. Y por lo que respecta a Ordoño, nunca más se supo: Permaneció entre los sarracenos y pagó con llorar sus penas ${ }^{104}$.

99 AL-MAQQARI; vid. SANCHEZ-AlboRnOZ, La España musulmana, pp. 371-373, según versión inglesa de Gayangos y francesa de Dozy.

100 AHN, Becerro Gótico de Sahagún (= BGS), f. 42r-v; ed. MíngUEZ, Colección de Sahagún, I, doc. 196.

${ }^{101}$ AHN. Clero, Sahagún, carp. 874, núm. 20; ed. ID., ibid., doc. 197.

102 IBN 'IDARI; "Il arriva à Cordue des envoyés de Sancho fils de Rodmir, qui était en désaccord avec le prince infidèle de Galice Ordoño, son cousin paternel. Ces gens, qui avaient entre autres avec eux 'Abd er-Rahman ben Djah'haf, kadi de Valence, et Ayyoub ben et-T'awil, arrivérent en rebi' II (mai) et transmirent à El-Mostançir la lettre par laquelle Sancho ben Rodmir répondait à ce qui lui et tous ses sujets reconnaissaient l'autorité du Prince des croyants"; trad. Fagnan, Histoire de l'Afrique et de l'Espagne, p. 389.

103 IBN JALDUN; trad. MACHADO MOURET, p. 357.

${ }^{104}$ SAMPIRO, Crónica; trad. GÓMEZ-MORENO, Introducción a la Historia Silense, p. CVI. 


\section{HASDAY Y LOS JUDÍOS [940-975].}

Por lo general, en al-Andalus los judíos fueron peor vistos que los cristianos. Por ejemplo, en 936 un informador norteafricano de 'Abderrahman III denominaba despectivamente al califa fatimí (934-946) como el judío Abu l-Qasim ${ }^{105}$. Sabemos también que el obispo de Córdoba que se entrevistó en 954 con el embajador alemán, Juan de Gorze, se expresó en estos términos: Nosotros somos... condescendientes con estos musulmanes... les debemos aún el consuelo de dejarnos usar de nuestras propias leyes... y cultivan nuestro trato con agrado y placer, cuando, por el contrario, aborrecen del todo a los judíos ${ }^{106}$. Incluso el propio Hasday fue objeto de recelo hacia su persona por parte de algunos poderosos, según el testimonio de otro judío: Los consejeros llenos están / de ira y furor / con caras malhumoradas; / también los nobles ${ }^{107}$, llegando incluso un faqí a intentar la ruina de Hasday al dirigirse al califa con estas palabras: El Profeta, que tú no honras, sino por su causa, dice éste [Hasday] que es mentiroso ${ }^{108}$. Pero en general hay que pensar que en al-Andalus los judíos eran respetados, como viene a confesar el propio Hasday en su carta al rey de los jazares: Vivimos tranquilos en el país de nuestra residencia ${ }^{109}$. Y Lévi-Provençal cree que "nada nos permite afirmar, a pesar de algunas alusiones poéticas, en que es difícil apoyarse, que... los judíos, estuviesen obligados durante el califato a llevar una insignia despreciativa peculiar, especie de banda o de cinturón de determinado color (zunnar), destinada a distinguirlos de los musulmanes" ${ }^{110}$.

Además, Hasday tuvo completa libertad para potenciar un importante mecenazgo que convirtió a la capital cordobesa en el centro de la cultura judía de su tiempo, mediante la acogida de no pocos hebreos procedentes de los lugares más dispares, traductores, médicos, geógrafos, matemáticos y astrónomos, químicos, filósofos y, cómo no, filólogos y poetas ${ }^{111}$, como los citados Menahem b. Ya‘aqob

\footnotetext{
105 Ibn Hayyan; trad. Viguera y Corriente, Crónica del califa, p. 288.

${ }^{106}$ Vita Ioannis abbatis Gorziensis; vid. SIMONET, Historia de los mozárabes de España, p. 608.

107 Dunas Ben Labrat; vid. Del Valle, La Escuela Hebrea de Córdoba, p. 68.

108 Averroes, Poética; vid. ID., ibid., p. 66.

${ }^{109}$ Carta de Hasday a los Jazares; trad. ID., ibid., p. 330.

${ }^{110}$ Vid. LÉvi-ProvenÇAL, E. (1965). España musulmana hasta la caída del califato de Córdoba (711-1031 de J.C.). Instituciones y vida social e intelectual, traducción e introducción por Emilio García Gómez (Historia de España dirigida por Ramón Menéndez Pidal, V). Madrid: Espsa Calpe, p. 125 y p. 278, n. 72.

111 Vid. a modo de ilustración el índice recogido por AlBi Romero, G. (1993). "Índice de científicos musulmanes y judíos hispanos en la España medieval". Proyección histórica de España en sus tres culturas. Castilla y León, Andalucía y el Mediterráneo, III. Valladolid, pp. 225-233.
} 
b. Saruq y Dunas ben Labrat, quien no dejó de constatar en uno de sus poemas la ingente labor de su protector (sus riquezas van a parar a Sura / a cambio de libros / para instruirles en los preceptos / dulces como la miel) ${ }^{112}$; una labor protectora que también fue recordada luego por otros muchos, entre los cuales al-Harizi:

Junto a él [Hasday] se congregaron todos los sabios de su generación, resplandecientes como brillantes luminarias, para servir la sabiduría a todos los buscadores de Dios. Los llenó con el espíritu de Dios, con sabiduría e inteligencia, con conocimiento profuso, con el arte de elaborar pensamientos... Desde aquel tiempo, las ciencias hicieron brecha en España, los indóciles aprendieron la doctrina y los poetas siguieron a los indóciles. Su generosidad hizo cantar la lengua de los mudos, abrieron los corazones que estaban cerrados hasta el punto que le compusieron poemas gratísimos [...] Entonces se abrieron sus ojos con el arte poético, se extendieron los cielos, aparecieron visiones divinas. En su tiempo se expandió la sabiduría en Israel, puesto que él fue para la ciencia detentador y redentor. Después de aquel tiempo las mentes brillantes se apagaron ${ }^{113}$.

Así pues, Hasday fue un hombre celebrado por sus propios correligionarios, entre los que llegó a alcanzar la dignidad de nasi o "príncipe" de la comunidad judía (que según Del Valle ya lucía probablemente en 948), lo que le convertía en "el supremo poder judicial sobre los miembros de las comunidades judías de alAndalus" y en "representante oficial... ante el califa"114, dignidad que ilustran, por ejemplo, el citado Dunas ben Labrat (habla con reposo, pausadamente, cuando se sienta a las puertas de la ciudad) y otro poeta anónimo contemporáneo (temed la punta de su espada y la picadura de su escorpión cuando se sienta con su consejo a hacer justicia a los pobres) ${ }^{115}$. Hasta el desafortunado Menahem b. Ya'aqob b. Saruq llegó a decirle directamente que era para todo hombre noble y honrado... generoso y natural... espejo... noble de ingenio y talento... apreciable, perfecto sin defecto, y ello a pesar del trato miserable que había recibido por parte de él, negra mancha en la brillante trayectoria de Hasday, que llegó a decir a Menahem: Si pecaste, te traje la corrección: si no pecaste, te he proporcionado la vida del mundo futuro ${ }^{116}$.

112 Dunas Ben Labrat; vid. Peláez Del Rosal, Hasday ibn Saprut en la corte de Abderramán, p. 301.

113 Al-Harizi; vid. Del VAlle, La Escuela Hebrea de Córdoba, pp. 59-85, la cita en p. 83.

114 Vid. ID., ibid., p. 53 y p. 75.

115 Anónimo; trad. ID., ibid., p. 76 y n. 122.

${ }^{116}$ Menahem Ben SARUQ; trad. ID., ibid., p. 83. 
Según el citado Lévi-Provençal "el mérito principal que le ha atribuido (a Hasday) la tradición judía posterior ha sido el de revigorizar el judaísmo andaluz y el haber hecho de Córdoba un activo foco de estudios talmúdicos en el momento mismo en que tales estudios comenzaban a extinguirse en las academias rabínicas de Siria y el 'Iraq"117. Y Sáenz-Badillos añade por su parte que por ese entonces, "los judíos andalusíes, que se consideran descendientes de las más ilustres familias de Jerusalén, piensan que es hora de soltar amarras y desarrollar su propia vida", precisamente desde la llegada de Moseh ben Hanok, "que probablemente procedía de Italia y poseía un saber tradicional de raíces palestinenses", el cual vino a convertirse "en el máximo dirigente espiritual de al-Andalus con la ayuda de Hasday, el gran mecenas de la comunidad judía de Córdoba en los días brillantes del Califato":

Esto fue lo que ocurrió: salió de la ciudad de Córdoba un comandante de navíos cuyo nombre era Ibn Rumahis; lo había enviado el rey ismaelita de Sefarad 'Abd al-Rahman an-Nasir... a capturar los barcos cristianos y las ciudades costeras. Fueron hasta la costa de Israel, rodearon el mar de Grecia y sus islas y encontraron un barco en el que viajaban cuatro grandes sabios, que iban desde la ciudad de Bari.... capturó Ibn Rumahis el barco y apresó a los sabios: el primero. R. Husi'el... otro, R. Moseh, padre de R. Hanok... el tercero $R$. Še"mariah ben $R$. 'Elhanan; del cuarto ignoro su nombre [...] Llegó el comandante a Córdoba y vendió allí a $R$. Moseh y $R$. Hanok su hijo, y los rescataron los hombres de Córdoba [...] Había en Córdoba una sinagoga llamada... de Midras, y un juez llamado R. Natán que era piadoso y grande. Pero los sefarditas no eran expertos en las palabras de nuestros maestros... pese a lo cual, con lo poco que sabían, hacían comentarios e interpretaciones más o menos correctas [...] Cuando escucharon el juez y los discípulos sus palabras [de R. Moseh] se sorprendieron y... R. Natán, el juez... les dijo: «Yo ya no soy el juez; ese hombre que viste de saco, el viajero, es mi maestro y yo seré su discípulo desde hoy mismo y vosotros debéis nombrarlo juez de la comunidad de Córdoba». Así lo hicieron [...] Pretendió entonces el comandante [Muhammad b. Rumahis] recuperarlo volviéndose atrás de su venta, pero no se lo autorizó el rey, que se había alegrado mucho de escuchar que los judíos de su reino no necesitaban a los hombres de Babilonia ${ }^{118}$.

117 Vid. LÉVI-PROVENÇAL, España musulmana, pp. 128-129.

118 ABRAHAM IBN DAUD; vid. SAÉNZ-BADILLOS, Literatura hebrea, p. 19-20. 
Y es conocida la carta que en 953 remitió a Hasday el gaón de Pumbedita, Aarón ha-Kohen bar Sargado $(+960)^{119}$, en la que también se deja constancia del que ya era su famoso mecenazgo:

Tú conoces a los sabios y a sus discípulos (sabes) de qué manera se sustentan, debido a que conoces el aprieto de los sabios, sus apuros económicos, su escasez de alimentos y de habituallas [...] llegaron cuestiones de vuestra patria... que os habéis hecho un nombre distinguido y que habéis logrado gran fama como la de los grandes de Israel y que habéis seguido a vuestros padres mirando por la afrenta de las academias [...] ahora, luz de mis ojos, te hizo el Señor nuestro Dios torre alta para los sabios, fortaleza para los principales, refugio para los discípulos, sostén para los vacilantes... acuérdate de mí con tus dones generosos... continuarás (enviándome) de modo regular tus cartas con tus saludos, tus particularidades y tus cuestiones, ya sea sobre la Biblia, la Misná o el Talmud para que te dé respuesta conforme nos ha instruido el Señor... que se mantenga tu bienestar y se acreciente tu sabiduría, tu dominación, el ingenio de tus acciones, tu bondad, por siempre jamás. Salvación ${ }^{120}$.

Pero además, en su calidad de alto funcionario y director de aduanas, Hasday estaba en inmejorable ocasión para contactar, según su criterio, con muy diversas personas venidas a Córdoba (comerciantes, viajeros, legados, sabios y prisioneros), desde Amalfi, Cerdeña, Argel, Egipto y Persia ${ }^{121}$. Y en este sentido, la carta escrita por Hasday al rey de los jazares, nos muestra a las claras su enorme preocupación por las comunidades judías que vivían en remotos lugares, los propios jazares entre ellos, sobre los que poseyó información que él mismo dice haber recabado a través de viajeros (llegaron a la tierra de mi señor, el rey, dos hombres de vuestra tierra, el uno... sabio, prudente y de mucha lectura; el otro... también hombre sabio) o de diplomáticos (a todos estos embajadores que traen dones les inquiero siempre acerca de nuestros hermanos, el resto salvado del exilio, por si acaso han oído algo acerca de la liberación del resto que se consume en el trabajo sin haber encontrado holganza), con buenos resultados en ocasiones, como ocurrió cuando llegaron los embajadores de Constantinopla con dones y una carta de su rey para

${ }^{119}$ Vid. Del Valle, La Escuela Hebrea de Córdoba, p. 40, n. 15: "Los gaones (= excelencias) eran los presidentes de las academias de Sura y Pumbedita que eran nombrados por el exilarca... o jefe político de las comunidades judías babilónicas. Su competencia en las cosas del Talmud hizo de ellos una autoridad indiscutida en toda la ecumene judía, pero sobre todo en los países islámicos por la unidad política que se introdujo en un principio con el califato".

${ }^{120}$ Carta de un gaón de Pumbedita; trad. ID., ibid., pp. 366-375.

${ }^{121}$ Carta de Hasday a los Jazares; trad. ID., ibid., p. 337 y p. 338. Vid. etiam IBN HAYYAN; trad. Viguera y CORRIENTE, Crónica del califa, p. 347 y p. 365. 
nuestro rey, les pregunté... y me dijeron que era cosa cierta, que el nombre del reino era Jazaria y que entre Constantinopla y aquél país había quince días de navegación por mar, mientras que por tierra eran muchas las naciones intermedias. El nombre del rey reinante era Yosef... que eran poderosos y poseían un ejército fuerte $e^{122}$.

E incluso sabemos que Hasday tuvo contacto con los judíos del sur Francia (Ifranya), y concretamente los de la ciudad de Toulouse (Tulyusa), donde, a fin de conmemorar anualmente la traición del Iscariote, los judíos tenían que hacer entrega de 30 libras de cera al obispo de la ciudad en la víspera de Pascua, de forma que en cierta ocasión, la bofetada que acostumbraba dar el obispo al oferente llegó a ser tan desmedida que (tal vez por una mala caída) le causó la muerte. Según Pelaéz del Rosal "la carta de Hasday fue enviada por medio de Samuel, miembro de la embajada remitida por el califa al rey Otón I y entregada a su paso por Toulouse", sin que en este caso tuviera éxito su mediación ${ }^{123}$.

Y de igual modo con los judíos del sur de Italia, bajo el dominio bizantino, como consecuencia de la persecución decretada contra ellos por el emperador Romano I Lecapenos (919-944) ${ }^{124}$, a los que socorrió con éxito Hasday, mediante el envío de sendas cartas al que ya era su sucesor Constantino VII Porfiriogénito, y a la emperatriz Helena (hija de Romano I), aprovechando la partida de la embajada califal hacia Constantinopla, con los embajadores bizantinos venidos en $949^{125}$.

Del Valle constata asimismo cómo a petición del propio Hasday "el hijo del gaón Sa’adia, le escribió una carta narrándole la vida de su padre", y que "Dunas ben Tammim (nacido en Kairuán a principios del siglo X) compuso un tratado astronómico, referido probablemente al calendario judío: Hemos explicado ya eso y hemos añadido figuras en el libro que compusimos y enviamos a Abu Yusuf Hasday ben Ishaq ${ }^{126}$. Y es bien sabido que, gracias a su renombre, emigraron hacia al-Andalus no pocos judíos provenientes de los más lejanos países, según puso de manifiesto Moseh ibn 'Ezra':

122 Carta de Hasday a los Jazares; trad. Del Valle, La Escuela Hebrea de Córdoba, pp. 330, 333 y 338.

${ }^{123}$ Vid. Peláez Del Rosal, Hasday ibn Saprut en la corte de Abderramán, p. 75.

${ }^{124}$ Vid. BeinarT, H. (1994). Los judíos de la Andalucía musulmana : Al-Andalus y el Magreb. Madrid, p. 139.

${ }^{125}$ Vid. PelÁez Del Rosal, Hasday ibn Saprut en la corte de Abderramán, pp. 74-75.

${ }^{126}$ Vid. Del Valle, La Escuela Hebrea de Córdoba, p. 81, n. 138. 
En su tiempo se despertaron los ánimos adormecidos y sacudieron su sopor al darse cuenta de las obras que propulsaba aquel varón, de la nobleza y magnanimidad de sus propósitos, así como de la alteza de su alma generosa y de la rectitud y bondad de su carácter. Él supo... importar los tesoros de la sabiduría desde todas las ciudades lejanas; él fortificó las columnas de la ciencia, rodeándose de sabios procedentes de Siria y Babilonia... él les dintiguía mucho con su favor, facilitándoles toda clase de medios para el logro de sus fines y para llegar al colmo de sus deseos ${ }^{127}$.

En efecto, gracias a Sa'id b. Sa'id al-Qurtubi sabemos que antes de Hasday los judíos del califato se veían precisados a recurrir a los judíos de Bagdad en lo concerniente a su ley religiosa, así como para fijar su calendario y las fechas de sus fiestas. Hacían venir desde donde ellos el cálculo relativo a un (cierto) número de años, y por ese medio sabían (el momento en) que se abrían sus cielos y los comienzos de sus años. Cuando Hasday entró en la relación con al-Hakam [II] y consiguió junto con él los favores... obtuvo de su señor que hiciese traer los escritos hebraicos existentes en el Oriente que él deseaba: entonces enseñó a los judíos de al-Andalus lo que ignoraban antes ${ }^{128}$. De manera que su labor continuó incansable (tras la muerte de 'Abdarrahmán III en 961) en los días de al-Hakam II, según el musulmán Ibn Usaibi’a: Fue el primero en hacer conocer a los judíos de al-Andalus su derecho, historia y otras ciencias. Antes los judíos de Al-Andalus tenían que recurrir a sus correligionarios de Bagdad... y... cuando Hasday estuvo al servicio de Al-Haquem y gozaba de su estima, recurrió a él para hacer venir del oriente todas las obras judías que deseaba. Fue así como los judíos de Al-Andalus pudieron conocer lo que ignoraban y no tuvieron tanta dificultad como antes ${ }^{129}$. Y así vivió siempre, fiel a su labor, hasta que le vino la muerte, acaecida "en 975, un año antes que al-Hakam", según Beinart ${ }^{130}$, sucediéndole como líder de los judíos, ya bajo el mandato de Almanzor, el magnate cordobés Ya‘aqob ibn Yau ${ }^{131}$.

${ }^{127}$ Moseh Ibn Ezra; Vid. MaEso, Un jaenés ilustre, p. 71.

${ }^{128}$ Vid. CASTAÑo, J. (2002). "Los documentos hebreos de León en su contexto prenotarial". Judaísmo Hispano. Estudios en memoria de José Luis Lacave Riaño, II. Madrid: Junta de Castilla y León; Diputación Provincial de Burgos; The Rich Foundation , Consejo Superior de Investigaciones Científicas, p. 459-481, y p. 464, n. 18, citanto literalmente: "Sa'id al-Andalusi (siglo XI)... Libro de las categorías de las naciones (Kitab Tabaqat al-Umam), estudio y traducción Felipe MAíllo SALGADO (Madrid, 1999), p. 150".

${ }^{129}$ IBN SA'ID apud Ibn Usaibi'a; vid. Del VAlLe, La Escuela Hebrea de Córdoba, pp. 85 y 82-83.

${ }^{130}$ Vid. BeinART, Los judíos de la Andalucía musulmana, p. 140.

${ }^{131}$ Vid. SAÉNZ-BADILLOS, Literatura hebrea, p. 40. 


\section{LOS JUDÍOS DE LEÓN DESPUÉS DE HASDAY [HASTA 1000].-}

Valga cuanto antecede para poner bien de manifiesto la preocupación de Hasday por todos los judíos de cualesquiera coordenadas conocidas en su tiempo, ¿cómo no pensar, en consecuencia, que pusiera asimismo su insaciable mirada en el afianzamiento de la modesta comunidad judía que tal vez existía en su tiempo en la "urbe regia" legionense?, ¿o como no pensar, si es que no existía todavía dicha comunidad hebrea, que Hasday no propiciara su establecimiento en la "urbe regia" (durante su larga estancia de siete meses en León), hasta convertirla en la más próspera del noroeste hispano?

En su carta al rey de los jazares, la curiosidad de Hasday por aquella lejana comunidad hermana se nos muestra enorme:

«Déme a conocer mi señor, el rey, cuál es la extensión de su país, su longitud y anchura, cuáles las ciudades amuralladas y cuáles las abiertas, si tienen regadío artificial o natural, hasta dónde llegan sus dominios... el número de provincias sobre las que dominas y el montante de tributos que te pagan, si te entregan los diezmos, si mi señor reside habitualmente en una ciudad fija del reino o se recorre todos sus territorios del reino, si existen islas vecinas, si en ellas ha judaizado la población, si administra directamente la justicia a su pueblo o si ha establecido jueces... el comportamiento de las caravanas que van a la región de mi señor, el rey. Hazme saber cuántos reyes reinaron antes de ti, cuáles fueron sus nombres, cuánto tiempo reinó cada uno, en qué lengua habláis... Hemos perdido nuestra gloria, estamos inmersos en el exilio y no podemos replicar absolutamente nada cuando diariamente se nos dice: "cada pueblo tiene su reino, pero vosotros carecéis de memorial en la tierra". Cuando supimos la fama de mi señor, el rey, del poderío de tu reino y de la multitud de tus soldados, quedamos sorprendidos, pudimos alzar la cabeza... el reino de mi señor se convirtió para nosotros en argumento de réplica» ${ }^{132}$.

Así pues, cualquiera que hubiese sido la importancia numérica de la comunidad judía leonesa con anterioridad a 941 (previsiblemente poca), resulta impensable bajo todo punto de vista (humano, social, cultural, económico y religioso) que un hombre como Hasday no mostrara una detenida atención por su número, estado, actividad, contratiempos y necesidades, y que los hebreos leoneses no resultaran en todo caso muy fortalecidos y favorecidos, a través de su directa mediación, bajo los reinados de Ramiro II (+ 951), de Ordoño III (+ 956), y de "su paciente" Sancho

132 Carta de Hasday a los Jazares; trad. Del VAlle, La Escuela Hebrea de Córdoba, pp. 343345. 
"el Gordo" (+ 966), mediante un atento seguimiento desde Córdoba, según sabemos que hacía con frecuencia, gracias al testimonio de al-Harizi: Dispensó a todos los que le pedían bendiciones sin fin... este príncipe dio nueva vida a los ignorantes con el rocío de su magnificencia y arrastró los corazones de los exiliados con las cuerdas de su generosidad. Hizo correr la voz: "Todo el que sea del Señor que venga a mí y yo correré con todas sus necesidades". Se reunieron en torno a él... de los países cristianos y árabes, de oriente y occidente. Dispuso ante ellos la mesa de su generosidad. La nube de su majestad se paró ante ellos, la columna de fuego de su gloria iluminó sus rostros ${ }^{133}$. E incluso cabe contemplar la posibilidad de que fuese ahora precisamente, por iniciativa de Hasday (entre 941 y 975), cuando los judíos de León recibieran los antiquísimos libros que todavía conservaban dos siglos después (en 1196) según el testimonio de Abraham Zacut:: Los 24 libros, escritos como 600 años antes, pues los había escrito R. Mosé ben Hil.lel, por cuyo nombre fue llamado Hil·lelí. Eran muy exactos (depurados) y por ellos corregían todos los libros. Yo mismo he visto los dos escritos de los profetas primeros y los posteriores, de una escritura de letras grandes y esmeradas ${ }^{134}$.

De forma que no es improbable que la colonia judía de León se encontrara inmersa ya en esa situación de relativas tranquilidad y prosperidad cuando, por fin, sus individuos comienzan a aparecer en los documentos de forma regular, dando señales seguras de vida en comunidad tan sólo dos años después de la muerte de Hasday, esto es, durante la minoría de Ramiro III (967-985), según diversos testimonios:

- Una escritura de 16 de junio de 977, que menciona a las claras la existencia de un judío llamado Abzecri, que ya era propietario de una viña en la actual "Candamia" (en las afueras de León, junto al río Torío), entonces llamada "Monte Aúreo" (vinea in Monte Aureo... terminum de Abzecri iudeo usque in carrale que discurrit de civitate ad Covellas, de III $^{a}$ vero parte carrale que exit de rivo Torio) ${ }^{135}$.

- En León habría nacido en 981 (si no fue inmigrante) el judío Ya‘aqob bar R. Ishaq ibn Qoth, que a los 45 años (el 18 de julio 1026) sabemos asesinado la ruta jacobea: Esta es la sepultura de Mar Ya'aqob bar R. Ishaq ibn Qoth, el cual fue asesinado en el camino de Sa[nt Yago?, Sahagún?]. ¿Que Dios

133 AL-HARIZI; vid. ID., ibid., pp. 82-83.

134 ABraham ZACUT; vid. CANTERA, F. (1943). "Nuevas inscripciones hebraicas leonesas". Sefarad, pp. 335-336, n. 3.

${ }^{135}$ AHN, BGS, ff. 143v-144v; ed. MínGUEZ, Colección diplomática de Sahagún, doc. 290. 
vengue su sangre!... y falleció el viernes día veinte del mes de Tammuz del año del año setecientos y ochenta y seis, y murió de edad de cuarenta y cinco años ${ }^{136}$.

- Y otra carta datada el 6 de abril de 984, que refiere la venta realizada por el matrimonio Julián y Materna al hebreo Vita, y a su mujer doña Vita, así como a Abraham y a su mujer Justa (tibi Uita ebreo et uxor tua domna Uita et Abraham et uxor tua Justa), consistente en una viña en Alija de la Ribera, junto a León (uinea nostra propria quos abemus in loco uocitando in Alixa $)^{137}$. Un cultivo que siempre fue de la preferencia de los judíos leoneses durante las dos siguientes centurias.

- Unos años después, entre 994 y 999, reinando ya Vermudo II (985-999), debido a los delitos cometidos por el citado hebreo Vita, el monarca le confiscó una villa de su propiedad en la ya referida Alija de la Ribera, junto al río Bernesga (uilla quos sita est in ripa amne Uernesiga uocitata Alixa, quod fuit de Uitas hebreo et presit eam rex domnus Uermudus), que fue entregada al presbítero castellano Ascarico ${ }^{138}$.

- Hacia 994/1001 nos consta que tenían propiedades en Valdesogo los judíos Iucef y Crescente, colindantes con una viña (in Ualle de Sabugo, et est ipsa uinea determinata: de Iuzeph et de Crescente ebreos) ${ }^{139}$.

136 Vid. CANTERA, Nuevas inscripciones, p. 320, vid. etiam pp. 347-351, señalando cómo "el tratamiento de Mar, Señor (frecuente en todo el Norte de África y en España hasta el siglo XI, debido al predominio arameo y la influencia que ejercieron las escuelas babilónicas durante el Gaonado), se ofrece en todas las inscripciones hebraicas de León que conocemos $\mathrm{y}$, como estudio Loeb, es corriente en las escrituras hebreas leonesas", y añadiendo que "no aparece hoy en la inscripción bien patente el nombre de esa carretera o camino... conjeturamos que sea Sahagún, más pudiera ser Santiago". vid. etiam ID., Un epitafio habraico más, p. 153: "Notemos ante todo el tratamiento de Mar «Señor», de raigambre aramea, usual en todas las inscripciones hebreas de León, y que también se lee en algunos documentos de Toledo en el siglo XIII"; CANTERA, F. (1974). "Juderías medievales de la provincia de León". Archivos Leoneses, 55-56, p. 140, constatando: "Asesinado en la carretera de Sa(nt Yago, Sahagún?)".

${ }^{137}$ ACL, nº 1342; ed. E. SÁEZ y C. SÁEZ, Colección catedral de León, II, doc. 495.

138 Carta de 1018: ACL, TL, ff. 107r-108r; ed. RuIz AsENCIO, Colección catedral de León, III, doc. 756. Ahora bien. Sabemos que Ascarico se documenta desde 994 (ed. ID., ibid., doc. 565) y hasta la muerte del rey en 999: "Et ipse magister Ascarigus dum uidit migratus a seculo rex domnus Ueremudus, perrexit ad Castellam" (ed. ID., ibid., doc. 756), de modo que entrambas fechas habrá que situar, pues, la rebelión del hebreo Vitas de Alija.

139 ACL, TL, f. 414v; ed. ID., ibid., doc. 610, sin data, y añadiendo que "la fecha propuesta corresponde a la cronología del abad Teuda de Abellar", que gobernó en 994/1001. 
- Por otro documento, fechado el 13 de noviembre de 997, sabemos que Xaba y sus hijos Fortes y Jacinta vendieron al hebreo Abozaque y a su mujer Zete (tibi Abozaque ebreo et uxor sua Zete) la heredad que tenían en el río Porma (ereditate nostra probia quem habemus in locum predictum in Porma ad Ofilones) ${ }^{140}$.

- Un preciso testimonio nos confirma que al filo de 999 la comuniad judía ya era relativamente numerosa en León, cuando un tal Nuno Donnítiz, tras la conquista de León por Almanzor (en el invierno de 994/995) ${ }^{141}$, pidió una heredad al propio rey Vermudo II (uenerunt filiis hysmaelitarum in Legione... erexit autem se Nunus Donnitiz et... petiuit ipsa hereditate ad rege), en Castrillo de la Ribera (hereditatem... in Kastrello), localidad sita en las inmediaciones de León, la cual pasó, muerto él, a sus pequeños hijos por concesión del mismo rey Vermudo, necesariamente antes del año 999 en que murió el monarca (post morte autem de ipse Nunno... tenente ipsa hereditate ipsos pueros de dato principis domno Ueremudo rex), aunque luego fue tomada por su viuda doña Auria (madre también de los dos menores) para ponerla a la venta "tanto a cristianos como a judíos" (cepit mater eius domna Auria ipsa hereditate ad uendere tam christianis quam et ad iudeis), de forma que fueron dos hebreos leoneses, Xab Xaia y Jacob, apodado Trobajo, los que la compraron al fin (conparauerunt iudeis... Xab Xaia et Iacob quod uocitant Trepalio), y los que luego convirtieron la tierra en viñedo (et posuerunt uineas ipsos iudeos in ipsas terras) ${ }^{142}$.

- Y aún cabe mencionar otra carta leonesa fechada poco después del milenio (el 16 de febrero de 1002), que confirma un tal Abraham ebreo, relacionada con la venta de una propiedad in territorio Legionensis, en cualesquiera de los actuales Antimio de Arriba o de Abajo (loco predicto Antimio) ${ }^{143}$.

Así pues, los hebreos que vivieron en León durante estos 25 últimos años del siglo $\mathrm{X}$ inmediatos a la muerte Hasday, $\mathrm{y}$ los que vivieron en las décadas siguientes, aparecen como propietarios de tierras. Si algo es seguro es que fueron la viticultura y la vinicultura dos actividades muy propias de ellos, al igual que en al-

140 ACL, nº 159; ed. ID., ibid., doc. 579.

${ }^{141}$ Vid. CARRIEDO TEJEDO, M. (1986). "Las campañas de Almanzor contra la ciudad de León: Su conquista definitiva en 994 según las fuentes musulmanas y cristianas". Estudios Humanísticos, 8, pp. 165-180.

142 Carta de 1015: ACL, TL, ff. 350v-351v; ed. RuIz AsENCIO, Colección catedral de León, III, doc. 737.

143 ACL, TL, f. 326r-v; ed. ID., ibid., doc. 737. 
Andalus. Y consta asimismo que la mujer judía fue propietaria de bienes raíces. Parece seguro que ejercieron también oficios artesanos (al menos la orfebrería) y cabe sospechar con cierto fundamento que los hubo mercaderes. Su filiación paterna sólo consta de forma muy excepcional en los documentos latinos que los mencionan, la materna nunca; y en ocasiones son apodados por el que seguramente fue su lugar de residencia (caso del citado Jacob "Trobajo", actual Trobajo de Cerecedo, término municipal de León).

No se diferenciaron de los cristianos en los escasos incidentes que protagonizaron (desórdenes en un caso y compra ilegal de terrenos en otro, antes registrados), y desde luego tampoco consta que fueran discriminados de forma activa hasta el "Concilio de Coyanza" del año 1055, cuando ya se había operado un cambio de dinastía en León, con el coronamiento del vascón Fernando I (10381065): Ningún cristiano more con judíos dentro de la misma casa, ni coma con ellos. Si alguno quebrantase esta disposición nuestra, haga penitencia durante siete días. Si se negare a hacerla, excomúlguesele durante un año, siendo persona mayor, $y$ reciba cien azotes si fuera menor ${ }^{144}$.

De forma que la aparición documental en 975-1000 de los hebreos leoneses Abzecri, Vita y doña Vita, Abraham y Justa, Iucef, Crescente, Abozaque y Zete, Xab Xaia, Jacob "Trepalio" y Abraham, probablemente no es más que un pálido reflejo del previsible notable impulso dado a mediados del siglo X por el cordobés Hasday a la comunidad judía leonesa durante 941-975, la única (no se olvide) que es posible documentar durante el siglo $\mathrm{X}$ en todo el noroeste hispano ${ }^{145}$, $\mathrm{y}$ hoy sabemos que vivieron radicados sucesivamente:

$1^{\circ}$ ) Durante todo un siglo (desde 975 hasta 1085/1090) en las pequeñas localidades leonesas situadas a ambas márgenes del corto curso conjunto del Torío y el Bernesga, hasta su confluencia en el Esla: Alija de la Ribera, Castrillo de la Ribera, Marialba de la Ribera y Valdesogo, y al otro lado del río en Trobajo de Cerecedo, Villacedré, Vilecha y Antimio). Por no hablar de muchas viñas de su

${ }^{144}$ Concilio de Coyanza; trad. RodRíguez, La judería de la ciudad de León, pp. 67-68.

145 Hay que advertir que la mención de judíos en Castrogeriz en 974 es aislada, por más que pueda deducirse la existencia de una comunidad judía en el hecho de que el conde García Fernández equipare los pechos por homicido entre cristianos y judíos: "Si homines de Castro matarent Iudeo, tantum pectec pro illo quomodo pro christiano, et libres similiter hominem villarum"; ed. ZABALZA Duque, M. (1998). Colección diplomática de los condes de Castilla: edición y comentario de los documentos de los condes Fernán González, García Fernández, Sancho García y García Sánchez. Valladolid: Junta de Castilla y León, Consejería de Educación y Cultura, doc. 49. Un testimonio incomparable, en todo caso, con las noticias conocidas hoy sobre los judíos leoneses en el siglo X. 
propiedad en los dos montes que se elevan a un lado y otro de la ciudad: "Monte Frío" (del lado del río Bernesga) y "Monte Áureo" (del lado del Torío) ${ }^{146}$.

$2^{\circ}$ ) Otra centuria más (también de esplendor y gran relevancia) en el "Castrum Iudeorum", esto es, desde que Alfonso VI los agrupó entre 1085 y 1090 en el que siempre había sido conocido hasta entonces como "Castrum Regis", junto al río Torío $^{147}$, y hasta que en 1196, en los días del leonés Alfonso IX (1188-1230), dicho castro fue sometido al saqueo y la destrucción por parte de las tropas de Alfonso VIII de Castilla y de Pedro II de Aragón: Don Alonso, rey de Castilla, vino a conquistar a León con ayuda de don Pedro, rey de Aragón, y trajo muy grandes ejércitos de gentes de armas de Castilla, y de Aragón, e puso luego cerco sobre el Castro de los Judíos, que está una milla de la ciudad de León, e tomólo por fuerza $^{148}$.

$3^{\circ}$ ) Y por último, el posterior establecimiento durante otros 300 años más al abrigo de los muros de la propia capital leonesa, pero convertida ya en una más de las muchas comunidades hebreas que por entonces abundaban en toda la España cristiana, hasta la general expulsión ordenada por los Reyes Católicos en $1492^{149}$.

146 Vid. CARriedo TEJEDo, M. (2008). "Judíos en la provincia de «Gallaecia»". EM, 24.

147 Vid. Carriedo Tejedo, M (2008). "Los orígenes de Puente Castro, León (897-1197) : de "Castro del Rey» a "Castro de los Judíos»". El Reino de León en la Alta Edad Media, XII. León: Centro de Estudios e Investigación "San Isidoro"; Caja España; Archivo Histórico Dicoesano, pp. 339-363. Con razón han podido fechar en 1091/1092 los profesores CASTAÑO, J. y AVELLO, J.L. (2001). "Dos nuevos epitafios hebreos de la necrópolis del Castro de los Judíos (Puente del Castro, León)". Sefarad, 61-2, p. 311 y n. 32. Y de todas formas la primera lápida con fecha completa conocida corresponde al 19 de abril de 1094 (reg. CANTERA, Juderías medievales de la provincia de León, p. 140).

${ }^{148}$ LuCAs De TuY, Vida de Santo Martino; ed. España Sagrada, XXXV, p. 401. Nos limitamos a dar, a modo ilustrativo, este pasaje, sin duda el más desconocido.

${ }^{149}$ Remitimos para este período a las páginas de RoDRíguez FERNÁNDEZ, J. (1969). La judería de la ciudad de León. León: Centro de Estudios e Investigación "San Isidoro"; Caja España; Archivo Histórico Dicoesano. 